\title{
Immune responses in the thyroid cancer microenvironment: making immunotherapy a possible mission
}

\author{
Robert C Mould, Jacob P van Vloten*, Amanda W K AuYeung*, Khalil Karimi and \\ Byram W Bridle
}

Department of Pathobiology, Ontario Veterinary College, University of Guelph, Guelph, Ontario, Canada *(J P van Vloten and A W K AuYeung contributed equally to this work)
Correspondence should be addressed to B W Bridle Email

bbridle@uoguelph.ca

\begin{abstract}
The incidence of thyroid cancers has been steadily increasing worldwide over the past few decades. Although five-year survival rates for differentiated thyroid cancers are upwards of $90 \%$, clinical outcomes for patients with undifferentiated, recurrent and/or metastatic disease are often dismal despite conventional interventions. As such, there is a demand for novel treatment options. Cancer immunotherapy represents the ultimate form of personalized medicine by leveraging the specificity and potency of a patient's immune system to kill their tumor. The thyroid cancer microenvironment is rich in immunological cells, making it a reasonable candidate for immunotherapy. This review maps out the immunological features of thyroid cancers and how these can be modulated. There are surprising immunological consequences of conventional therapies that demand attention. Also, hormonal modulation of the immune system is highlighted as a unique and confounding feature of thyroid cancers. A variety of cuttingedge immune-based therapies are discussed, with an emphasis placed on how these can be integrated with the current standard of care. Several high priority areas in need of research are also highlighted.
\end{abstract}

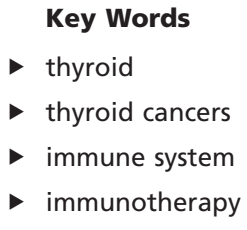

Endocrine-Related Cancer (2017) 24, T311-T329

\section{Introduction}

The most common endocrine cancers are those that originate in the thyroid gland (Kilfoy et al. 2009). Although the reported incidence of thyroid cancers has increased steadily over the past few decades, this may be due, in part, to improved detection as a result of technological advancements in diagnostic imaging (Kent et al. 2007). However, it is thought that societal increases in risk factors such as obesity are also a contributing factor (Han et al. 2013, Morris et al. 2013). The vast majority of thyroid cancers (i.e. $~ 90 \%$ of diagnosed cases) are derived from differentiated follicular cells and can be subdivided into two main types: papillary and follicular, which are the most and second most common subtypes, respectively (Cabanillas et al. 2016, Howlader et al. 2016). Papillary and follicular thyroid cancers are generally associated with good prognoses (up to a 97\% five-year survival rate) if conventional treatments are implemented (Cabanillas et al. 2016). The medullary form represents only $~ 5 \%$ of thyroid cancers, originates from the parafollicular cells, is usually moderately differentiated and associated with a five-year survival as high as $86 \%$. Poorly differentiated thyroid carcinomas and the anaplastic (undifferentiated) types account for less than $5 \%$ of cases. Although rare, these cancers often present with metastases.

This paper forms part of a special section on Immunotherapy and Cancer. The guest editors for this section were Joanne Y Y Ngeow and Laura S Ward. 
Disconcertingly, metastatic anaplastic thyroid carcinomas are virtually untreatable and, therefore, almost universally fatal, with median survival of less than six months after diagnosis (Cabanillas et al. 2016, Howlader et al. 2016). The size, stage and subtype of thyroid cancer influence the course of therapy. Typical standard of care treatment includes thyroidectomy followed by radioiodine therapy and suppression of thyroid-stimulating hormone (TSH) (Mazzaferri \& Jhiang 1994). In cases of advanced or metastatic disease, where survival rates drop precipitously, additional interventions such as chemotherapy, tyrosine kinase inhibitors and radiation therapy are often implemented (Howlader et al. 2016). The most pressing need for improving outcomes for patients is the development of novel ways to effectively treat recurrent and metastatic thyroid cancers. To this end, cutting-edge immunotherapies show promise for providing oncologists with a novel array of therapeutic tools in the near future (Couzin-Frankel 2013). However, nuances will need to be taken into consideration when applying these in the context of thyroid cancers.

Immunosurveillance is a process that allows the immune system to detect potentially dangerous neoplasias in the body and typically prevents the manifestation of cancerous growths (Dunn et al. 2004). However, if neoplastic cells are not eliminated at this early stage of development, a state of equilibrium can become established between transformed cells and the immune system. At this point, acquisition of mutations that facilitate evasion from immunological effector mechanisms can lead to uncontrolled growth, resulting in the development of clinical cases of cancer. The concept of immunological pressure driving the development of immunoevasive phenotypes in cancers is known as immunoediting (Dunn et al. 2002). Immunotherapies aim to potentiate a patient's immune system, while exploiting its inherently exquisite specificity, to kill cancer cells with minimal side-effects. The potential for immunological pressure to kill neoplastic cells but also edit tumors has resulted in two approaches to immunotherapy. One is to quantitatively and/or qualitatively increase tumor-specific immune responses. The other is to counteract the immunosuppressive potential of cancers. The most efficacious immunotherapies will likely combine both aspects.

\section{Immunological cell subsets in thyroid cancers: identifying friends and foes}

The immunosurveillance and immunoediting concepts provide a framework for understanding how immunological effector cells can mediate tumor regression, while immunosuppressive cells can promote the growth of cancers. Indeed, there is a growing body of literature to support correlations of the number and type of tumor-infiltrating leukocytes with either positive or negative clinical outcomes in patients (Gooden et al. 2011, Gentles et al. 2015). Several subsets of leukocytes have well-defined roles in thyroid cancers prior to therapeutic interventions.

\section{Myeloid cells}

Macrophages, dendritic cells and neutrophils are mature cell types that develop from the myeloid lineage during hematopoiesis. In contrast, myeloid-derived suppressor cells (MDSCs) are phenotypically heterogeneous myeloid cells that have not fully matured (Gabrilovich \& Nagaraj 2009). Although MDSCs are rare in healthy individuals, they are found in higher numbers in cancer patients, where they have potent immunosuppressive potential (Marvel \& Gabrilovich 2015). As such, an increased number of MDSCs is often associated with a poor prognosis. In thyroid cancers, the presence of MDSCs may even be a useful biomarker for distinguishing benign nodules from cancerous lesions. Specifically, there seems to be an association between higher preoperative levels of circulating MDSCs and thyroid cancers as compared to patients with benign nodules or other non-cancerous thyroid diseases (Suzuki et al. 2013, Angell et al. 2016). There also seems to be a correlation between numbers of circulating MDSCs and aggressive growth characteristics of differentiated thyroid cancers (Angell et al. 2016). Prognoses could potentially be improved in thyroid cancer patients by either differentiating MDSCs into mature myeloid cells or depleting or functionally inhibiting them with various treatments, including some chemotherapeutics, nitric oxide inhibitors, tyrosine kinase inhibitors (e.g. sunitinib) and/or bisphosphonates, amongst others (Najjar \& Finke 2013). Notably, sunitinib has recently demonstrated anti-tumor activity in advanced differentiated thyroid cancer (Bikas et al. 2016). Although the benefit seen with sunitinib treatment has not been definitively attributed to MDSC depletion, it is known to augment MDSCs, which correlates with enhanced tumor-specific responses generated by cancer vaccines in preclinical models (Wesolowski et al. 2013).

The density of tumor-associated macrophages (TAMs) varies in the different pathologic subtypes of thyroid cancers (Jung et al. 2015). In particular, anaplastic thyroid cancers were found to have the most TAMs, with their

Published by Bioscientifica Ltd. 
numbers correlating with poorer prognoses (Jung et al. 2015). Although the average number of TAMs tends to be lower in papillary thyroid cancers, there is a similar correlation with clinical outcomes, including more lymph node metastases, larger tumors and reduced survival (Ryder et al. 2009, Kim et al. 2013, Fang et al. 2014, Jung et al. 2015). In vitro data also suggested that TAMs could promote invasiveness of a human thyroid cancer cell line through interleukin (IL)-8 secretion (Fang et al. 2014). This mechanistic link was further corroborated by enhanced metastasis of human papillary thyroid cancer cells following treatment of immunodeficient mice with IL-8 (Fang et al. 2014). However, a retrospective study of patients with thyroid cancers found a favorable association between the number of tumor-infiltrating macrophages and improved disease-free survival (Cunha et al. 2012). Additional and more detailed research will be required to resolve these apparently conflicting results. Specifically, efforts should be made to differentiate inflammatory type 1 vs suppressive type 2 TAMs because a high ratio in favor of the former subset usually confers better outcomes in other cancer types (Zhang et al. 2014a, Yuan et al. 2015).

Dendritic cells (DCs) are central players in the induction of immunity, as they are critically involved in the role of antigen presentation and regulation of immune cell function via secretion of cytokines. Under normal homeostatic conditions, DCs are rarely found in the thyroid gland. However, the number of DCs is increased in human papillary thyroid cancers (Hilly et al. 2013). Despite their role in the induction and regulation of immune responses, DC density in tumors was not found to be associated with disease-free survival. This may be the result of tumor-infiltrating DCs often adopting an immature or paralyzed phenotype, with low expression of costimulatory molecules, high expression of regulatory molecules, resulting in impaired antigen presentation (Harimoto et al. 2013, Tran Janco et al. 2015). Immature DCs are not only poor inducers of $\mathrm{T}$ cell and natural killer (NK) cell-mediated responses, but they can also inhibit immune responses via the production of suppressive cytokines such as IL-10 and TGF- $\beta$ (Scouten \& Francis 2014). Regulatory T cells and DCs appear to collaborate in the immunosuppressive conditioning of the tumor microenvironment. In a model of pancreatic ductal adenocarcinoma, regulatory $\mathrm{T}$ cells were found to suppress the function of tumor-infiltrating DCs, by preventing expression of costimulatory ligands necessary for the activation of $\mathrm{CD}^{+} \mathrm{T}$ cells (Jang et al. 2017). Although similar mechanistic data is lacking in the case of thyroid cancers, regulatory $\mathrm{T}$ cells and DCs are enriched in human papillary thyroid cancers (Yu et al. 2013). Therefore, interruption of regulatory $\mathrm{T}$ cell and DC interactions in thyroid tumors would likely be of benefit. Several strategies to directly restore the functions of tumor-infiltrating DCs could be employed, including blockade of immunosuppressive pathways such as those associated with PD-1, secretion of IL-10 and production of lactic acid (Tran Janco et al. 2015).

Neutrophils are typically the first responders during inflammation. Interestingly, the neutrophil-tolymphocyte ratio (NLR) has been explored as a prognostic indicator in thyroid cancers. A high NLR correlated with more aggressive forms of thyroid cancers (e.g. poorly differentiated type such as anaplastic) and represented a poor prognostic marker for these cancers (Cho et al. 2015). Similarly, higher NLR was strongly associated with larger tumor sizes (Liu et al. 2013). These results are in agreement with a recent report that identified neutrophils as the leukocyte subset with the strongest negative correlation with patient outcomes across cancer types (Gentles et al. 2015). Unlike MDSCs, the NLR could not be used to distinguish between benign and malignant lesions (Liu et al. 2013).

\section{Natural killer cells}

Natural killer (NK) cells can spontaneously kill cells deemed to be dangerous to the host, including cancer cells and are, therefore, presumed to be important in cancer immunosurveillance (Guillerey et al. 2016). NK cells differentiate their targets from 'healthy self' by integrating signals from multiple inhibitory and activating receptors. Nevertheless, few solid tumors have shown to be responsive to NK cell-mediated immunotherapy due to resistance to NK cell-induced lysis, as well as poor homing and infiltration of NK cells into tumors (Wennerberg et al. 2014). However, anaplastic thyroid cancer cell lines are known to be sensitive to NK cell-mediated cytolysis in vitro, suggesting thyroid cancers could benefit from immunotherapies that incorporate the recruitment of activated NK cells into the tumor microenvironment (Wennerberg et al. 2014). Additionally, the cells secreted CXCL10 when stimulated with IFN- $\gamma$ and demonstrated an ability to attract CXCR3+ NK cells (Wennerberg et al. 2014). If this observation could be confirmed in an in vivo animal model of anaplastic thyroid cancer, where many other key cell types and factors may impact NK cell functions, then adoptive transfer of ex vivo-expanded NK cells may be a useful treatment option.

Published by Bioscientifica Ltd 
One major barrier to effective immunotherapy with NK cells is tumor immunosuppression. Intratumoural NK cells display a suppressed phenotype when compared to blood-derived NK cells. It has been demonstrated that anaplastic thyroid cancer cells expressing high levels of COX2 co-cultured with NK cells resulted in downregulation of NKG2D expression on NK cells, when compared with co-culture of COX2-negative cell lines (Wennerberg et al. 2014). NKG2D is an activation receptor for NK cells, which potentiates the lysis of tumor cells. This downregulation was rescued by administration of neutralizing antibodies to prostaglandin E2. Others have also shown NK dysfunction in tumor-bearing mice. Pahar et al. demonstrated reduced splenocyte-mediated cytotoxicity in thyroid tumor-bearing LSL-BrafV600E/TPO-Cre mice compared to normal LSL-BrafWT/TPO-Cre mice (Parhar et al. 2016). NK and CD8 ${ }^{+} \mathrm{T}$ cells were important mediators of this cytotoxicity, and the reduced cytotoxic capacity of splenocytes in tumor-bearing mice was partially restored by treatment with exogenous IL-12 and anti-TGF $\beta$ (Parhar et al. 2016).

NK cell therapy relies on a high number of functional NK cells. Many studies have explored the use of cytokines to improve NK cell proliferation and cytotoxicity. In particular, IL-15 is critical for NK cell maturation and survival (Cooper et al. 2013). Stimulation with IL-15 enhances NK cell functions and cytotoxicity against pancreatic duct adenocarcinoma in vitro (Audenaerde et al. 2017). Ex vivo supplementation of IL-15 and IL-21 enhanced NK cell proliferation and cytotoxicity against rhabdomyosarcoma cells, and adoptive transfer of these ex vivo-expanded NK cells even reduced tumor growth in a xenograft model when used in combination with radiation therapy in a proof-of-concept study (Wagner et al. 2017). Both studies also demonstrated an increase in expression of NKG2D with IL-15 stimulation (Audenaerde et al. 2017, Wagner et al. 2017). Others have sought methods to supply IL-15 in vivo; for instance, genetically modifying NK cells to express IL-15 in order to support NK cell survival and proliferation (Liu et al. 2017). Genetic alterations have also been used to boost NK cell activity, such as expression of chimeric antigen receptors to redirect their specificity against cancer cells (Liu et al. 2017). These strategies present the opportunity to overcome the resistance of cancer cells toward NK cell-mediated killing. Further research is warranted to understand the full extent of NK cell dysfunction within thyroid tumors to facilitate the rational design of effective therapeutic strategies to circumvent this suppressive phenotype.

\section{T cells}

Lymphocytic infiltration is associated with favorable outcomes in numerous types of cancers including metastatic melanomas (Clemente et al. 1996), ovarian (Zhang et al. 2003, Sato et al. 2005), colorectal (Galon et al. 2006, Teng et al. 2015) and breast cancers (Wang et al. 2016). In human papillary thyroid cancers, lymphocyte density is also associated with better overall survival and lower recurrence of tumors (Matsubayashi et al. 1995, Kuo et al. 2017). In another study, actively replicating lymphocytes, which were identified based on expression of the proliferation-associated nuclear antigen Ki-67, were identified as a particularly strong predictor of extended disease-free survival in both children and young adults (Gupta et al. 2001). CD8 ${ }^{+} \mathrm{T}$ lymphocytes are a key focus in the field of immunotherapy due to their dominant natural role in eliminating cancer cells (Schreiber et al. 2011). Infiltration of $\mathrm{CD}^{+} \mathrm{T}$ cells into thyroid tumors was associated with improved diseasefree survival (Cunha et al. 2012). In the same study, both $\mathrm{CD}^{+}$and $\mathrm{CD}^{+}{ }^{+} \mathrm{T}$ cells, as well as $\mathrm{B}$ cells were shown to be favorably correlated with reduced tumor sizes (Cunha et al. 2012). In contrast, increased infiltration of CD8+ $\mathrm{T}$ cells was found to be associated with a higher risk of relapse in another study (Cunha et al. 2015). However, the majority of the $\mathrm{T}$ cell infiltrates lacked expression of granzyme B, which tends to identify cells with cytolytic capacity. A higher resolution biomarker for positive prognoses in thyroid cancers may be quantification of $\mathrm{CD}^{+}$granzyme $\mathrm{B}^{+} \mathrm{T}$ cells. The expression of cytolytic proteins granzyme and perforin is regulated by IL-2 and IL-15 (Janas et al. 2005, Tamang et al. 2006). A therapy that could induce the expression of, or deliver IL-2/IL-15 to the thyroid cancer microenvironment may arm $\mathrm{T}$ cells with cytotoxic granules required to kill neoplastic cells. Systemic delivery of IL-2 can be toxic, but novel ways of preferentially getting IL-2 to a tumor has been explored such as IL-2 linked to a tumor-associated ligand or having it encoded by an oncolytic virus (Dasgupta et al. 2003, Kang et al. 2012).

Generally, tumor-infiltrating $\mathrm{T}$ lymphocytes tend to adopt an exhausted or dysfunctional phenotype due to the immunosuppression exerted by the cancer microenvironment. Inhibitory receptors like programmed death ligand-1 (PD-1) represent immunological checkpoints and provide a natural mechanism to dampen $\mathrm{T}$ cell responses via induction of anergy or apoptosis (Chen et al. 2015), to reduce the risk of autoimmunity following induction of protective responses. In the case of cancers,

Published by Bioscientifica Ltd. 
autoreactive T cells specific for 'cancerous self' are precisely what are required to eliminate tumors. Unfortunately, tumors tend to promote upregulation of inhibitory receptors such as PD-1 on T cells while simultaneously expressing high levels of cognate ligands like PD-L1 and PD-L2. This results in a decreased production of interferon (IFN)- $\gamma$ and concomitant reduction in cytopathic potential, compared to extra-tumoral lymphocytes from the same patient (Ahmadzadeh et al. 2009). Notably, expression of PD-1 seems to be a characteristic of thyroid tumor-infiltrating $\mathrm{CD}^{+}{ }^{+}$and $\mathrm{CD}^{+}{ }^{+} \mathrm{T}$ cells (Bastman et al. 2016). This suggests that checkpoint inhibitor therapies may be an effective way to reinvigorate cytotoxic $\mathrm{T}$ cell responses in thyroid cancers.

Regulatory $\mathrm{T}$ cells are involved in shutting down immune responses and their presence correlates with disease progression and may encourage metastases to lymph nodes in various cancers (Halvorsen et al. 2014). Regulatory $\mathrm{T}$ cells are known to be present in papillary thyroid cancers and may be involved in promoting more aggressive disease (French et al. 2010). Other regulatory subsets of $\mathrm{CD}^{+} \mathrm{T}$ lymphocytes include $\mathrm{T}$ helper 17 cells and follicular helper $\mathrm{T}$ cells, but their roles in thyroid cancers have not been studied thoroughly. Due to a paucity of data, the prognostic value of $\mathrm{CD} 4^{+} \mathrm{T}$ cells in thyroid cancers remains unclear. Arguably, evaluating the $\mathrm{CD}^{+}$cytotoxic:regulatory $\mathrm{T}$ cell ratio in thyroid cancers would be in important future direction of research, since this has proven to be a strong prognosticator in other cancers (Gooden et al. 2011). A recent paper identified a population of $\mathrm{T}$ lymphocytes in thyroid cancers that did not express CD4 or CD8 (Imam et al. 2014). These doublenegative $\mathrm{T}$ cells were found in much higher numbers in thyroid tumors as compared to the glands of patients suffering from autoimmune diseases of the thyroid (Imam et al. 2014). In this study, the intratumoural doublenegative $\mathrm{T}$ cells appeared to reduce the proliferation and cytokine production of neighboring activated effector $\mathrm{T}$ cells (Imam et al. 2014). As such, reducing the number of these cells in thyroid cancers might assist immunemediated therapies.

Taken together, the milieu of thyroid cancers appears to be amenable to immunomodulatory treatments. Exploring treatment modalities to remove or convert cells of myeloid origin from immunosuppressive to immunostimulatory phenotypes appears to be warranted in the context of thyroid cancers. Moreover, enhancing the activation and infiltration of effector NK and T cells and preventing their shutdown could potentiate the regression of thyroid cancers. While substantial progress has been made in charting an immunological map for thyroid cancers, better differentiation of immunological subsets such as TAMs and cytotoxic T cells with functional characteristics is still required to resolve some apparently conflicting results.

\section{Hormones $\mathrm{T}_{3}, \mathrm{~T}_{4}$ and TSH: confounding immunomodulatory factors that are unique to thyroid cancers}

Thyroxine $\left(\mathrm{T}_{4}\right)$ which gets converted to 3,5,3'-triiodoL-thyronine $\left(\mathrm{T}_{3}\right)$ are two hormones produced by the thyroid gland and are involved in the regulation of numerous mammalian metabolic processes. Of the two, $\mathrm{T}_{3}$ is, by far, the most potent stimulator of metabolism. Several studies have suggested that these hormones also have an impact on the immune system. For example, B cell development was shown to be suppressed in thyroid hormone-deficient mice (Foster et al. 1999). Also, high concentrations of $T_{3}$ were associated with an increase in the amount of complement proteins and the number and phagocytic activity of monocytes (Hodkinson et al. 2009). Moreover, physiological levels of $\mathrm{T}_{3}$ were demonstrated to induce the maturation of murine DCs (Mascanfroni et al. 2008). Similarly, $\mathrm{T}_{4}$ was found to be associated with higher concentrations of complement proteins and also higher neutrophil counts (Hodkinson et al. 2009). $\mathrm{T}_{4}$ concentration was also inversely correlated with the ratio of naïve to memory cytotoxic $T$ cells (Hodkinson et al. 2009). Taken together, these results suggest that higher concentrations of thyroid hormones could enhance innate and adaptive immunity, via maintenance of specific subsets and increased responsiveness to immune stimuli (Hodkinson et al. 2009). In another line of research, immunological parameters have been assessed in scenarios of non-cancer-related hyperthyroidism and hypothyroidism, in which thyroid-derived hormones are increased and decreased, respectively. In these disease settings, a wide variety of immunological functions are impacted, including antibody production, trafficking of leukocytes, proliferation of lymphocytes and generation of reactive oxygen species, as summarized in Table 1 (and reviewed by De Vito et al. 2011). Thyroid-stimulating hormone (TSH) is a pituitary hormone that stimulates the thyroid to produce $\mathrm{T}_{3}$ and $\mathrm{T}_{4}$. TSH can also have direct effects on the immune system. TSH enhanced antibody responses in vitro in a dose-dependent manner (Blalock et al. 1984, Klein 2006). It was also reported that TSH could induce 
Table 1 The effects of hyper- vs hypothyroidism on the immune system.

\begin{tabular}{|c|c|c|}
\hline Immune function & Hyperthyroidism & Hypothyroidism \\
\hline Antibody production & $\uparrow$ serum concentrations of $\lg G, \lg A$ and $\lg E$ & $\begin{array}{l}\downarrow \text { serum concentrations } \\
\text { of } \lg \text { and } \lg A\end{array}$ \\
\hline Monocyte migration & $\downarrow$ & No effect \\
\hline $\begin{array}{l}\text { Production of hydrogen } \\
\text { peroxide by activated } \\
\text { macrophages }\end{array}$ & $\downarrow$ & $\uparrow$ \\
\hline Phagocytic capacity & $\begin{array}{l}\uparrow \text { (polymorphonuclear granulocytes; } \\
\text { mediated by } \mathrm{T}_{3} \text { ) } \\
\uparrow \text { (monocytes; mediated by } \mathrm{T}_{3} \text { ) }\end{array}$ & $\uparrow$ (macrophages) \\
\hline NK cell activity & $\begin{array}{l}\text { In vitro spleen cells pre-incubated with } \\
\text { thyroxine increased NK cytotoxic activity } \\
\text { induced by IFN } \\
\text { Mice injected with T4 had increased } \\
\text { peritoneal NK cell activity }\end{array}$ & No data \\
\hline $\begin{array}{l}\text { Inflammatory markers } \\
\text { (C3 and C4) }\end{array}$ & $\begin{array}{l}\text { Association between higher T3 and T4 and } \\
\text { higher C3 and C4No difference }\end{array}$ & $\begin{array}{l}\uparrow \mathrm{C} 3 \text {; no differences in } \\
\text { serum C4 }\end{array}$ \\
\hline Memory T lymphocytes & $\uparrow$ (associated with elevated T4) & No data \\
\hline Splenic T cell \# & $\uparrow$ & $\downarrow$ \\
\hline Splenic B cell \# & $\downarrow$ & $\uparrow$ \\
\hline Splenic NK cell \# & $\downarrow$ & $\downarrow$ \\
\hline
\end{tabular}

References

Jafarzadeh et al. (2010),

Bittencourt et al. (2007)

Rosa et al. (1995)

Rosa et al. (1995)

Balázs et al. (1980), Rosa et al. (1995), Hodkinson et al. (2009)

Sharma et al. (1982), Provinciali et al. (1992)

Hodkinson et al. (2009), Jafarzadeh et al. (2010)

Hodkinson et al. (2009)

Watanabe et al. (1995)

Watanabe et al. (1995)

Watanabe et al. (1995)
NK cell activity and increase IL-2-induced proliferative responses of murine splenic lymphocytes (Provinciali et al. 1992). How TSH augments cells of the immune system in the thyroid tumor microenvironment remains an understudied area that requires further investigation. Patients with thyroid cancers that receive thyroidectomies often receive synthetic $T_{4}$ to compensate for hormonal deficiency from the resulting hypothyroidism. This is also known as TSH suppression therapy, since elevated levels of $\mathrm{T}_{4}$ cause a negative feedback loop that reduces production of TSH. Importantly, suppression of TSH is associated with a reduced incidence of recurrent disease (Biondi \& Cooper 2010). However, given the immunostimulatory potential of TSH, perhaps this adds to the debate of whether TSH suppression therapy should be used less often in lowrisk-of-recurrence patients, since it can also induce adverse events such as osteoporosis (Wang et al. 2015a). Currently, there is a body of literature highlighting immunological effects of non-cancer-related hypo- and hyper-thyroidism. A separate set of studies evaluating the neuroendocrine-immune axis have clearly demonstrated that thyroid-related hormones are immunomodulatory. However, there appears to be a large gap in knowledge where these fundamental biologies intersect in the context of thyroid cancers. Many patients with thyroid cancers will experience disturbances in thyroid hormone homeostasis. Specifically, full/partial thyroidectomies can cause hypothyroidism. This is often alleviated with the administration of exogenous $T_{4}$, which restores levels of this hormone, but suppresses TSH. As mentioned above,
TSH suppression may not be indicated as a treatment modality, particularly in patients with a low risk of cancer recurrence. Moreover, patients with Hashimoto's thyroiditis (HT) often develop hypothyroidism from chronic inflammation of the thyroid gland. This autoimmune disease has interesting implications for papillary thyroid cancers. A meta-analysis of patients with papillary thyroid cancers revealed that concurrent HT was significantly associated with a lack of lymph node involvement, an absence of extrathyroidal extension and prolonged recurrence-free survival, particularly among women (Lee et al. 2013). Paradoxically, the authors arrived at the conclusion that HT may actually contribute to the development of papillary thyroid cancers, despite simultaneously conferring a better prognosis (Lee et al. 2013). Importantly, this very unique case of immunecancer cell interplay could be an invaluable resource for discerning which immune cell infiltrates are tumourigenic and which ones are tumouricidal. Although rare, thyroid cancers can occur in patients with hyperthyroidism as well, which can complicate diagnoses, and may have implications for immune system function and clinical outcomes (Gabriele et al. 2003, Gulcelik et al. 2006, Yeh et al. 2013). We can extrapolate what is known in the fields of endocrinology and immunology to speculate on the immunomodulatory effects of thyroid cancers and subsequent clinical interventions (Fig. 1). In light of the interplay between TSH, $\mathrm{T}_{3}, \mathrm{~T}_{4}$, and the immune system, integration of immunotherapy with standard of care hormone replacement therapy may have unexpected 
Concurrent Hyperthyroidism

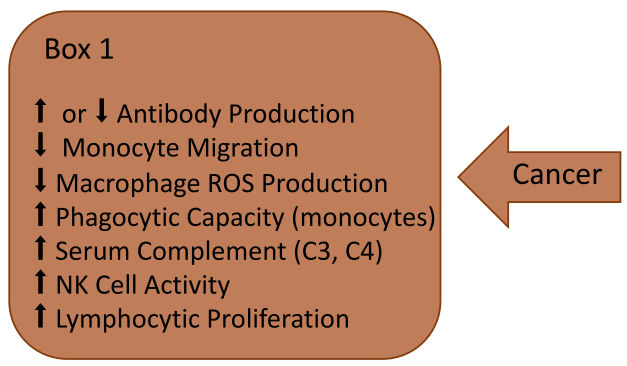

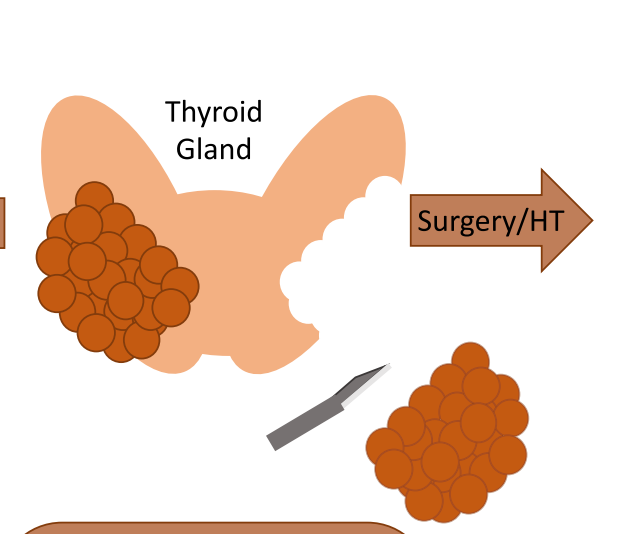

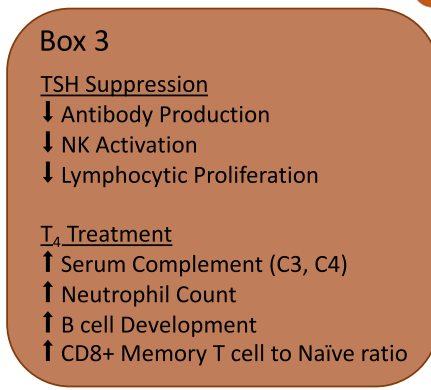

Hypothyroidism

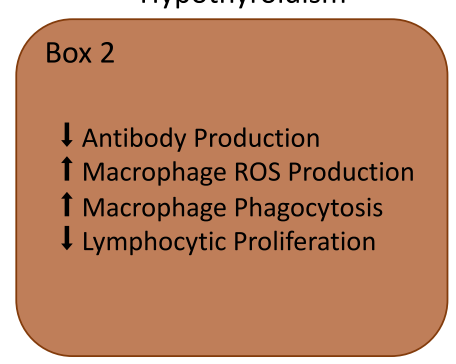

\section{Figure 1}

Predicted hormonal effects on the immune system of patients with thyroid cancers. Several immunological effects of hyper- and hypothyroidism have been defined in non-cancer-related scenarios. Similarly, thyroid gland-related hormones have known immunomodulatory functions. Although never directly assessed, these findings can be extrapolated to speculate on what might happen to the immune system of patients with thyroid cancers. Some patients experience hyperthyroidism concurrently with a growing tumour (Box 1). Hypothyroidism induced by partial or total thyroidectomy, or with concurrent Hashimoto's thyroiditis (HT) (Box 2), can be followed by a unique hormone profile following administration of thyroxine (T4) to suppress thyroid-stimulating hormone in an effort to reduce the risk of disease recurrence (Box 3). NK, natural killer cell; PMN, polymorphonuclear cell; ROS, reactive oxygen species.

outcomes. This is unique to thyroid cancers and should be highlighted as a high priority area for research.

\section{Perioperative considerations: minimizing surgery-induced immunosuppression}

Recurrent thyroid cancers can be notoriously difficult to treat, as neoplastic nodules can present in local soft tissues, nerves, lymph nodes and as distant metastases (Kim et al. 2017). Patients with recurrent thyroid cancers have a treatment history, following the standard of care framework, which can impact the immunological environment. For example, stage I, II and III patients usually have surgical removal of cancerous margins or the entire thyroid gland (Mazeh \& Chen 2011). Importantly, surgery and accompanying anesthesia are generally immunosuppressive, resulting in postoperative minimization of immunological cell numbers and functions critical to anticancer responses; especially $\mathrm{T}$ and NK cells (Hogan et al. 2011). The ratio of effector $T$ to regulatory $\mathrm{T}$ cells can be altered in favor of the latter, which is linked to the development of metastases, since regulatory
T cells are capable of orchestrating shutdown of innate and adaptive immune responses (Takeuchi \& Nishikawa 2016). The direct impact of surgery on the pre-existing anticancer cytotoxic $\mathrm{T}$ cell repertoire was demonstrated through an elegant cancer vaccine model (Ananth et al. 2016). Oncolytic adenovirus encoding a transgene for the melanoma-associated antigen dopachrome tautomerase was delivered to mice bearing B16-F10 lung metastases to induce tumor-specific cytotoxic $\mathrm{T}$ cells. Abdominal nephrectomy was performed to mimic major surgery, which resulted in direct suppression of dopachrome tautomerase-specific $\mathrm{T}$ cells. A reduction in both the number and functionality of cancer-specific $\mathrm{T}$ cells correlated with increased tumor burden and decreased survival, simulating clinical recurrence such as that observed following thyroid resection (Ananth et al. 2016).

Surgery-induced immune dysregulation is an underappreciated driver of recurrent disease, making it an important treatment point to consider introducing corrective immunotherapies. Several strategies have been implemented to diminish the immunosuppression from surgery and reduce risk of metastases. The use of

Published by Bioscientifica Ltd 
preoperative non-steroidal anti-inflammatory drugs can decrease physiological stress and relieve suppression of leukocytes, leading to increased anti-tumor responses in patients, as demonstrated by greater numbers of tumor-infiltrating $\mathrm{CD}^{+}$and $\mathrm{CD}^{+}{ }^{+}$effector $\mathrm{T}$ cells and a decrease in intratumoural gene expression of the regulatory $\mathrm{T}$ cell transcription factor FOXP3 (Lönnroth et al. 2008). Recombinant cytokine therapy can be delivered preoperatively as an immunostimulant, as in the case of IL-12 (Schwartz et al. 2008). Insufficient IL-12 is associated with limited IFN- $\gamma$ production by NK and $\mathrm{T}$ cells, leading to weak adaptive anti-tumor cytotoxic $\mathrm{T}$ cell responses. In preclinical models of breast cancer, recombinant IL-12 has been shown to improve anti-tumor responses by synergizing with an anti-HER2 monoclonal antibody (Jaime-Ramirez et al. 2011). In addition to IL-12, recombinant IL-2 has mediated moderate improvement in survival for patients with operable colorectal cancers (Brivio et al. 2006). The administration of systemic cytokines is often a double-edged sword, where efficacy is matched with toxicity, as in the case of IL-2 (Dhupkar \& Gordon 2017). To circumvent this issue, researchers have explored the use of vector-based therapeutics such as recombinant oncolytic viruses (OVs) to focus transgene expression inside the cancer microenvironment.

\section{Oncolytic virotherapy}

Oncolytic viruses have emerged in the clinic as promising vectored immunotherapeutics. OVs preferentially infect and replicate in tumor cells, where they can induce a broad inflammatory reaction by producing immunostimulatory viral proteins, lipids and nucleic acids that serve as pathogen-associated molecular patterns that can be sensed by sentinel cells in the immune system. Direct viral oncolysis also elicits secretion of damage-associated molecular patterns and release of tumor antigens. Therefore, OVs can provide a source of tumor antigens and danger signals required to promote antigen presentation to T cells. As such, OVs can function as endogenous personalized cancer vaccines (Chiocca \& Rabkin 2014). Further, leading OV platforms harbor immunomodulatory transgenes, such as the cytokine granulocyte macrophage colony-stimulating factor (GM-CSF), which can expand and mature dendritic cells, enhancing their immunotherapeutic potential (reviewed by Kaufman et al. 2015). T-VEC is a herpes virus that expresses GM-CSF that has received approval from the United States Food and Drug Administration for treating advanced melanomas (Andtbacka et al. 2016). OV transgene expression is preferentially driven in tumors, which can potentially avoid acute toxicities associated with systemic delivery of a recombinant cytokine. Indeed, T-VEC performed better than GM-CSF alone in terms of increasing overall survival in melanoma patients, indicating the advantages of cytokine delivery via an OV (Andtbacka et al. 2015). Recently, OVs have been administered perioperatively to target postoperative metastases (Tai \& Auer 2014). In this setting, there is striking evidence that OVs provide a multimodal counter to postoperative metastases by first directly infecting and destroying metastatic nodules and second, by acting as an adjuvant to stimulate the patient's immune system, mainly through activation of NK cells. Oncolytic poxviruses, such as vaccinia virus (VACV) and Orf virus (ORFV), when administered during the perioperative window in a murine melanoma lung metastasis model dramatically increased the number of activated NK cells (Tai et al. 2013, 2014). Moreover, a greater proportion of NK cells produced IFN- $\gamma$ in mice treated with VACV or ORFV with surgery than compared to surgery alone, which correlated with a decrease in tumor burden. Antibody-mediated depletion of NK cells in mice treated perioperatively with VACV or ORFV, proved their role in mediating efficacy. Another study that used Maraba virus showed similar results (Zhang et al. 2014b). OVs may be broadly applicable as perioperative immune-potentiating therapies and should, therefore, be given consideration as a way to counteract thyroidectomy-induced immunosuppression.

Multiple OVs have been studied both pre-clinically and in clinical trials for thyroid cancers (Guan et al. 2014). An oncolytic adenovirus, d1922-947, has demonstrated anti-thyroid cancer activity in a preclinical murine xenograft model (Passaro et al. 2016). In addition to its cytolytic activity, d1922-947 modulated the tumor microenvironment through decreased production of tumourigenic IL-8 and an increase in IFN- $\gamma$, coupled with an increase in anti-tumoral type 1 TAMs. Other OVs, including VACV, Newcastle disease virus and measles virus have been investigated pre-clinically for the treatment of anaplastic thyroid carcinomas. Unfortunately, however, these studies used xenograft murine models that, by definition, exclude the impact of the host immune system. Importantly, OV vectors based on adenovirus have progressed into clinical trials, with one phase II study nearing completion (ClinicalTrials.gov Identifier: NCT01229865, VB-111). In this study, 44\% of patients receiving a therapeutic dose of virus experienced
C 2017 Society for Endocrinology Printed in Great Britain
Published by Bioscientifica Ltd 
a reduction in tumor size. Preclinical studies to support more human trials would benefit from exploring OVs in orthotopic, immunocompetent murine models of thyroid cancer (Vanden Borre et al. 2014, Kirschner et al. 2016).

\section{Thyroid cancer vaccines}

Cancer vaccination is a rapidly growing field of immunotherapy used to invoke tumor-specific immune responses. New insights into how antigens are processed, presented and how cell-mediated immune responses are generated has paved the way for the development of many novel cancer vaccines (Guo et al. 2013). Moreover, a growing understanding of how tumors employ immunosuppressive cells and pathways to avoid their demise has reinvigorated the field with promising combination therapies (Guo et al. 2013). Designing a vaccine to specifically target thyroid cancers, or any cancer for that matter, can be a challenge. Various vaccine platforms have been developed, including whole cells, cancer-derived lysates, peptides and recombinant viral vectors, including OVs. Many of these immunization strategies rely on the identification of antigens that are exclusively or overexpressed in or on tumor cells. Lists of high-priority tumor antigens are an invaluable resource (Cheever et al. 2009) for the design of new vaccines. Very few immunogenic thyroid cancer-specific antigens with minimal risk of provoking off-target pathological autoimmunity have been identified, making this an understudied area with the potential to improve immunotherapies. Survivin has been shown to be differentially expressed in various subtypes of malignant human thyroid cancers when compared to benign and healthy thyroid tissues via reverse transcriptase-PCR (Chen et al. 2012, Waligórska-Stachura et al. 2014). Indeed, peptide-based survivin vaccines are being explored in various human solid cancer clinical trials (Miyazaki et al. 2011, Becker et al. 2012, Lennerz et al. 2014), and may be aptly suited for thyroid cancers. In one study, human epidermal growth factor receptor-2 was found to be overexpressed in $44 \%$ of follicular thyroid tumors $(n=45)$ and $18 \%$ of papillary thyroid tumors $(n=45)$ (Ruggeri et al. 2016). Telomerase reverse transcriptase (TERT) expression and activity in thyroid cancers are quite variable, but were estimated to be present in approximately $50 \%$ of samples across all subtypes of thyroid cancers from a metaanaylsis (Capezzone et al. 2009). Additionally, mutations in the TERT promoter region occurred in approximately $10-14 \%$ of papillary and follicular thyroid cancers, which correlated with increased expression and more aggressive clinical features (Muzza et al. 2015, Liu et al. 2016). Notably, distant thyroid cancer metastases had an increased prevalence (i.e. 52\%) of mutations in the TERT promoter (Melo et al. 2017). Recently, an adenoviral vector was made that expressed both TERT and VEGF-R2 and was found to successfully induce $T$ cells that recognized and were cytolytic in differentiated thyroid carcinomas (Wang et al. 2015). Importantly, simultaneous targeting of tumor cells and neovasculature appeared to have potent synergy. However, the authors noted a loss of fertility in mice vaccinated with their vector and suspected the VEGF-R2specific response was the culprit. Several clinical studies of TERT vaccine vectors have not shown autoimmune toxicities (Yan et al. 2013). Mutated BRAF genes are also common in thyroid cancers, occurring in approximately $45 \%$ of the papillary subtype (Xing 2005). Thyroid cancers with BRAF mutations typically have poorer outcomes for many unknown reasons, though it has been demonstrated that papillary thyroid cancers with constitutively active BRAF (V600E) express more PD-L1 compared to those with wild-type BRAF (53\% vs 12.5\%) (Angell et al. 2014a). In addition, tumors with mutated BRAF had lower CD8+:regulatory $\mathrm{T}$ cell ratios and greater infiltration of type 2 macrophages, suggesting this particular mutation correlates with an immunosuppressive microenvironment (Angell et al. 2014). Considering its prevalence, association with immunosuppression and poor outcomes, BRAF mutations appear to be a reasonable target for thyroid cancer vaccines. Interestingly, endogenous BRAF V600Especific $\mathrm{T}$ cells have been found in some melanoma patients (Andersen et al. 2004, Somasundaram et al. 2006). Notably from this study, metastatic lesions had lost the BRAF mutant genotype in two patients with BRAF mutant-specific T cells, suggesting selective pressure for wild-type BRAF tumor cells. Considering the V600E mutation's association with poorer prognoses, antigen escape-driven wild-type gene selection may be beneficial in thyroid cancers that have BRAF V600E mutations. Gene expression analysis found NY-ESO-1, a cancertestis antigen, in 15 of 23 (65\%) of medullary thyroid carcinoma samples (Maio et al. 2003). In another study, NY-ESO-1 was not expressed in several thyroid cancer cell lines. However, epigenetic modification of these cells with the hypo-methylating agent 5-aza-2'-deoxycytidine forced the expression of NY-ESO-1 in both in vitro and in vivo experiments (Gunda et al. 2014). In a similar study, another cancer-testis antigen, MAGE-A4, was evaluated in the same human cell lines and expression was also 
induced or enhanced by hypo-methylating agents (Gunda et al. 2013). Immunohistochemical analysis by another group failed to reveal expression of MAGE-A4 or MAGE-C1 in 50 differentiated thyroid tumors (Melo et al. 2011). Conversely, in another study, 31/85 (36.5\%) of papillary thyroid cancers had evidence of high levels of expression of MAGEA1-6 genes, although it was unclear whether this was reflected at the level of transcribed protein (Lee et al. 2013). Epigenetic modification may represent a useful tool to induce or enhance the expression of otherwise silent antigens in thyroid cancers, thereby making them more amenable to treatment with cancer vaccines. Another barrier to $\mathrm{T}$ cell-centric cancer vaccines, in addition to antigen scarcity, is loss of expression of MHC class I (Garrido et al. 2016). It was recently shown that $29 / 33(87.9 \%)$ of papillary thyroid cancers either failed to express MHC class I or expressed it at relatively low levels. Notably, expression of MHC class I could be upregulated on papillary thyroid cancer-derived cell lines when treated with selumetinib, a MEK1/2 inhibitor, and/or interferon (Angell et al. 2014). There is evidence from other cancer types that radiation therapy can increase the expression of MHC class I (Reits et al. 2006, Son et al. 2016). Unfortunately however, radiation therapy of thyroid cancer cell lines failed to increase MHC class I expression (Angell et al. 2014). CD8 ${ }^{+} \mathrm{T}$ cell-centric cancer vaccines should benefit from combination treatments that enhance the expression of MHC class I on neoplastic cells.

The generation of a tumor-specific adaptive immune response is reliant on antigen processing and presentation, which are two features that DCs do particularly well (Steinman 1991). As such, the development of DC-based vaccines has become an area of interest for the field of cancer immunotherapy. DC vaccines use a patient's progenitor cells, which get differentiated into DCs in the presence of cytokines such as GM-CSF and IL-4. The DCs can then be stimulated to initiate their maturation, loaded with tumor antigens and then injected back into patients. Proof-ofprinciple studies for using DCs to treat medullary thyroid cancers have been conducted using xenogenic calcitonin peptides (in mice) and allogeneic tumor cell lysates (in humans) (Papewalis et al. 2008, Bachleitner-Hofmann et al. 2009). Additionally, a phase I trial evaluated the safety of an autologous tumor lysate-pulsed DC vaccine (Kuwabara et al. 2007). Notably, all studies reported littleto-no adverse reactions to the DC vaccines. Interestingly, it was recently demonstrated that the thyroid hormone $\mathrm{T}_{3}$ could enhance the activation, maturation and antigenpresenting capacity of DCs in mice (Alamino et al. 2015).
Thyroid cancer patients can have dysregulated thyroid hormone levels. Therefore, administration of DC-based vaccines may be contraindicated when patients have low levels of $\mathrm{T}_{3}$. The interplay between thyroid hormones and DCs is an area that could be explored further to inform future clinical trials. The DC vaccine concept has been clinically validated by the United States Food and Drug Administration's approval of Sipuleucel-T in 2010, where the vaccine was able to extend median survival by approximately four months in men with metastatic castration-resistant prostate cancers (Kantoff et al. 2010). The field of DC vaccination is in its infancy, but this complex therapeutic strategy is being refined and improved each year (Butterfield 2013). Cost will continue to be a caveat for DC vaccines for the foreseeable future, but should not hinder the pursuit of this treatment modality as it has proven to be another useful tool in the cancer immunotherapy toolbox.

The primary aim of most cancer vaccines is to generate robust tumor-specific CD8 ${ }^{+}$Tcells. However, the therapeutic benefit of generating or having $\mathrm{CD}^{+} \mathrm{T}$ cells in a tumor is not always linearly correlated with survival, despite a wealth of data suggesting they are the primary effector cell subset responsible for tumor elimination. Decades of research have contributed to the elucidation of strategies utilized by tumors to induce potently immunosuppressive microenvironments (Drake et al. 2006). At the forefront of efforts to counteract tumor immunoevasion, are immune checkpoint blockade strategies. Immunological checkpoints rely on receptor-ligand interactions and can, therefore, be blocked with antibodies (Pardoll 2012). Cytotoxic T lymphocyte-associated protein-4 (CTLA-4) and programmed cell death protein-1 (PD-1) are the most studied targets of immune checkpoint blockade therapy in various cancers. CTLA- 4 is a receptor expressed on activated $\mathrm{T}$ cells that competes with $\mathrm{CD} 28$, for ligation of the costimulatory molecules CD80 and CD86 that are expressed on antigen-presenting cells. CTLA-4 ligation is inhibitory, while CD28 is stimulatory. Thus, blocking CTLA-4 can prevent T cell inactivation. PD- 1 on, the other hand, is transiently expressed by activated $\mathrm{T}$ cells and constitutively expressed on T cells with an exhausted phenotype. As such, anti-PD-1 therapy can restore the effector function of exhausted T cells (Jiang et al. 2015). PD-L1, the ligand for PD-1 is expressed by several types of thyroid cancers, albeit at low frequencies. Notably, out of 407 primary thyroid cancers, there was low-to-modest expression of PD-L1 in $6.1,7.6$ and $22.2 \%$ of papillary, follicular and anaplastic thyroid carcinomas, respectively 
(Ahn et al. 2017). Similarly, a relatively higher frequency of expression on anaplastic thyroid cancers was found by another group (Zwaenepoel et al. 2017). Yet, another study noted very low expression, or lack thereof, of PD-L1 in medullary thyroid cancers (Bongiovanni et al. 2017). Therefore, it would appear that techniques for PD-L1 interference may only be applicable to a small subset of thyroid cancers. Notably, anaplastic thyroid cancers, for which there is the greatest need for new treatments, may be most amenable to PD-L1 blockade. CTLA-4 blockade therapy is poorly studied in the context of thyroid cancers. However, anti-CTLA- 4 and anti-PD- 1 are currently being tested in several clinical trials for various solid tumor types. Results from these immunotherapies were encouraging in the treatment of melanomas (Larkin et al. 2015). In general, combining checkpoint blockade inhibitors with conventional or experimental therapies shows great promise (Duraiswamy et al. 2013, Engeland et al. 2014, Farkona et al. 2016). With the slow accrual of patients in clinical trials for mixed cancer types, time will discern the applicability of checkpoint inhibition for thyroid cancers.

\section{Adoptive cell therapy}

Adoptive $\mathrm{T}$ cell therapy (ACT) typically involves ex vivo expansion of blood or tumor-derived $\mathrm{T}$ cells followed by infusion back into a patient (Rosenberg \& Restifo 2015, Baruch et al. 2017). Once isolated, the T cells can either be selected for tumor specificity naturally or they can be genetically modified to recognize a particular tumor antigen. ACT has shown promise in hematological malignancies, but requires further optimization to see similar efficacy in solid cancers (Rosenberg \& Restifo 2015). A hurdle for ACT in the context of thyroid cancers will likely be the identification of $\mathrm{T}$ cells that can recognize highly expressed tumor antigens, that are rarely, or ideally, never expressed in healthy tissues. An alternative to acquiring naturally occurring tumor-associated antigen-specific $\mathrm{T}$ cells is to engineer $\mathrm{T}$ cells to express TCRs (chimeric antigen receptors) that recognize rationally selected targets with high affinity. One study demonstrated that adoptive transfer of hTERT ${ }_{865-873}$-specific TCR-engineered $\mathrm{T}$ cells into leukemia-bearing mice was able to inhibit tumor progression and prolong overall survival (Sandri et al. 2017). Since TERT is also overexpressed in thyroid cancers, adoptive transfer of $\mathrm{T}$ cells engineered to be TERT-specific may be an effective therapeutic candidate. Unfortunately, the enthusiasm toward ACT has declined due to the significant toxicities associated with them. For example, while patients treated with $\mathrm{T}$ cells engineered to express MAGE-A3-specific TCRs had tumors regress, they also experienced unexpected and severe neurological toxicities due to cross-reactivity to MAGE-A12, whose expression in the human brain was previously unrecognized (Morgan et al. 2013). One method that has shown potential in mitigating these unwanted adverse effects of $\mathrm{T}$ cells with chimeric antigen receptors is the incorporation of a 'safety switch', such as an inducible caspase 9 (iCas9) or suicide gene (Straathof et al. 2005, Tey 2014). The use of chimeric antigen receptor-expressing $\mathrm{T}$ cells expands antigen targets beyond peptide-MHC restricted specificity to include tumor-associated carbohydrates. Recently, a glycosphingolipid, Globo $\mathrm{H}$, was been found to be expressed on some thyroid cancers (Cheng et al. 2016). More research into thyroid cancer-specific antigens would be particularly valuable for immunotherapies in general, but especially ACT. A recent study used a murine model of anaplastic thyroid cancer to establish a sophisticated clinical monitoring technique (Vedvyas et al. 2016). Although ACT has not been sufficiently explored in the context of thyroid cancers, the therapy is robust enough to have broad applications, limited only by the availability of target antigens. Iterations of ACT for thyroid cancers will undoubtedly develop alongside ACTs targeting solid tumors in general, given the overlap in expression of antigens amongst tumors from various tissues.

\section{Immunogenic radiotherapy}

Iodine radiotherapy (RAI) has been used to treat patients with thyroid malignancies for decades with considerable success when combined with surgical resection for primary treatment, but does not improve the overall survival compared to surgery alone for recurrent disease (Coburn et al. 1994). RAI has historically been applied with other clinical assessments to detect recurrent disease, as RAI amasses in some recurrent metastatic lesions. In principle, radiation therapy can destroy local malignancies and distant metastases via an abscopal effect, which can release tumor antigens into an immunogenic microenvironment. The mechanism underlying the abscopal effect has been ascribed to the broad term immunogenic cell death (ICD) (Galluzzi et al. 2013). ICD classifies a diverse, yet overlapping consortium of cell death pathways that together culminate in the release of critically immunogenic damage-associated molecular patterns. 
These damage-associated molecular patterns, referred to as the hallmarks of ICD, are endogenous proteins and metabolites that undergo temporally scripted translocation to abnormal cellular compartments and are then recognized by innate immune cells, particularly DCs (Galluzzi et al. 2016). Expression of damage-associated molecular patterns by dying tumor cells increases the uptake of tumor antigens and provides maturation signals to professional antigen-presenting cells, thereby facilitating the activation of cancer-specific T cells. Thus, a strong ICD response is hypothesized to improve anticancer immune responses and improve clinical outcomes. Indeed, a retrospective study analyzing the outcomes of patients with breast cancers harboring a Toll-like receptor (TLR)-4 mutation, the main signaling receptor for the damageassociated molecular pattern high-mobility group box 1 (HMGB1), had reduced survival following chemotherapy with an ICD-inducer than patients with a fully functioning receptor (Apetoh et al. 2007, Ladoire et al. 2015).

The hallmarks of ICD include, but are not limited to, the exposure of the endoplasmic reticulum-resident chaperone calreticulin (CRT) on the outer plasma membrane leaflet, the extracellular translocation of adenosine triphosphates, and the passive diffusion of non-histone DNA-binding protein HMGB1 (Apetoh et al. 2007, Obeid et al. 2007, Michaud et al. 2011). Cell surface-expressed CRT is a ligand for CD91, offering a pro-phagocytic signal to antigen-presenting cells (Gardai et al. 2005). Adenosine triphosphates are recognized by the purinergic receptors P2Y2 and P2X7, which promote recruitment and maturation of DCs, respectively (Ghiringhelli et al. 2009, Junger 2011). Passive release of HMGB1 signals through TLR4, TLR9 and the receptor for advanced glycation endproducts (RAGE) to promote further maturation of DCs (Kang et al. 2013). However, the molecular translocation and signaling mechanisms that surround HMGB1 in ICD are complex and incompletely elucidated. An abundance of preclinical data and retrospective analyses support research to develop methods to accentuate ICD for clinical therapies, especially using protocols that are compatible with current standards of care (Garg \& Agostinis 2016). ICD has been underexplored in thyroid cancers; current studies are limited to evaluating hallmark damageassociated molecular patterns as prognostic markers or drivers of disease (Netea-Maier et al. 2008, Mardente et al. 2015, Guan et al. 2017). BRAF V600E mutations in papillary thyroid cancers appears to downregulate the expression of HMGB1, adding further evidence to suggest this mutation is immunosuppressive in nature
(Guan et al. 2017). ICD may be a critical mechanism for the success of radiotherapy, especially due to the high mutational load in thyroid cancers, which creates neoantigens; a prerequisite for robust $\mathrm{T}$ cell responses in immunotherapies like immune checkpoint blockade (Rizvi et al. 2015, Bailey et al. 2016). OVs may be wellsuited for the treatment of thyroid cancers because many have been shown to elicit ICD through divergent cell death pathways (Donnelly et al. 2013, Koks et al. 2015) and have synergistic effects when used in combination with standard of care such as radiotherapy (Harrington et al. 2010, Markert et al. 2014, Wilkinson et al. 2016) and chemotherapy (Kuryk et al. 2016, Binz et al. 2017). OVs may not only provide additional inflammatory stimuli in the form of pathogen-associated molecular patterns, but also limit the escape of tumors with mutations in key ICD pathways. The never-ending molecular arms race between eukaryotic cells, and viruses has endowed cells with the ability to succumb to multiple forms of death, especially when infected with viruses that manipulate those same pathways. This may be exploited in the context of OVs that can stimulate cells to die by an alternative immunogenic fashion, thus rescuing ICD and establishing and antitumor immune responses. A recent study demonstrated that an adenovirus-based oncolytic (d1922-947) synergized with radiotherapy both in vitro and in an in vivo xenograft murine model of anaplastic thyroid carcinoma (Passaro et al. 2013). Interestingly, this study demonstrated that enhanced killing of cancer cells was only seen when irradiation preceded viral infection. This was attributed to irradiation arresting cells in stages of the cell cycle that are more permissive to viral replication (G2/M) (Passaro et al. 2013). Conversely, in another study, pretreatment with an adenovirus enhanced the susceptibility of several human cancer cell lines to irradiation. The mechanism involved the adenoviral protein E1B55kDa, which is able to inhibit DNA repair machinery involved in sensing double-strand breaks in DNA (Kuroda et al. 2010). Though the outcomes of these studies differ in mechanisms of action, they provide the rationale to test combinations of OVs and irradiation in the context of thyroid cancers.

Despite its clinical success, radiotherapy is viewed as a double-edged sword; it can be attributed to the development of secondary cancers later in life. This is especially impactful for thyroid cancers, where radiation has been intimately linked to its development. Retrospective studies of testicular and Hodgkin lymphoma patients unveiled risk of thyroid cancers years following radiation therapy (Travis et al. 2005, Castellino et al. 2011). 
Limiting the negative impacts of radiotherapy may also be achievable through radiovirotherapy, using OVs engineered to carry the sodium iodide symporter gene NIS (Trujillo et al. 2013, Galanis et al. 2015). NIS is normally expressed on thyroid follicular cells and mediates uptake of radioactive iodine during RAI. OV-driven expression of NIS functions to concentrate radioisotopes with the additional advantages of specific targeting to cancer cells and immune stimulation by viral infection. Although mainly used to extend the use of radiovirotherapy to other solid cancers that do not have basal NIS expression, this method has been applied to thyroid cancers pre-clinically using a VACV carrying the human NIS (Gholami et al. 2011). This strategy could be used clinically to reduce the off-target effects of standard-of-care radiotherapy and offer potential to eliminate drug-resistant metastases that mediate disease recurrence.

\section{Conclusions and future directions}

Immunotherapy for thyroid cancers is indeed a possible mission. Various immunological cell subsets naturally infiltrate the thyroid tumor microenvironment. These leukocytes have prognostic value and play roles in tumor progression and elimination. Compared to other tumor types, there is a relative lack of research focused on the development of immunotherapies specifically for thyroid cancers. However, patients with thyroid tumors could feasibly benefit from the extensive development of immunotherapeutics targeting other solid tumors. Notably, many of the standard-of-care treatments already being used for thyroid cancers have previously unappreciated immunomodulatory effects. The effect of thyroid-derived hormones on immune responses in patients being treated with thyroid cancers remains a particularly understudied area. Developing a better understanding of this particular endocrine-immune axis will be essential to tailor immunotherapies for thyroid cancers. Perioperative treatments can help reduce the impact of surgery-related immunosuppression, potentially lightening the impact of thyroid tumor resection on any integrated immunotherapies. Radiation therapy, while inherently precarious, can induce tumors to become quite immunogenic, offering utility if used in combination with immunotherapy. Cancer vaccineinduced and/or adoptively transferred $\mathrm{T}$ cells targeting thyroid tumors hold the potential to be potent therapies, provided appropriate antigens can be identified. Developments involving checkpoint blockade inhibitors are also an exciting potential treatment modality for thyroid cancer and would be particularly amendable to potentiating methods designed to expand the repertoire of tumor-specific T cells. Moreover, vector-based vaccines such as oncolytic viruses, when armed with iodine symporter or cytokine transgenes could add an additional angle of attack. Overall, immunotherapies represent a particularly promising cutting-edge approach to treating thyroid cancers and will undoubtedly become effective components in the toolbox of future oncologists that treat this disease.

\section{Declaration of interest}

The authors declare that there is no conflict of interest that could be perceived as prejudicing the impartiality of this review.

\section{Funding}

Operational funding for BWB was from the Terry Fox Research Institute (Project \#1041). Stipend funding was from the following: for RCM: Art Rouse Cancer Biology Graduate Stipend (Pet Trust Foundation) and Ontario Veterinary College (OVC) Graduate Scholarship; for JPVV: Canadian Graduate Scholarship - Doctoral Award (Natural Sciences and Engineering Research Council of Canada) and Highly Qualified Personnel Scholarship (Ontario Ministry of Agriculture, Food and Rural Affairs); for AWKAY: Canadian Graduate Scholarship - Master's Award (Canadian Institutes for Health Research) and OVC Pet Trust Scholar's Program.

\section{References}

Ahmadzadeh M, Johnson LA, Heemskerk B, Wunderlich JR, Dudley ME, White DE, Rosenberg SA \& Dc W 2009 Tumor antigen - specific CD8 T cells infiltrating the tumor express high levels of PD-1 and are functionally impaired Tumor antigen - specific CD8 T cells infiltrating the tumor express high levels of PD-1 and are functionally impaired. Blood 114 1537-1544. (doi:10.1182/blood2008-12-195792)

Ahn S, Kim TH, Kim SW, Ki CS, Jang HW, Kim JS, Kim JH, Choe J-H, Shin JH, Hahn SY, et al. 2017 Comprehensive screening for PD-L1 expression in thyroid cancer. Endocrine-Related Cancer 24 97-106. (doi:10.1530/ERC-16-0421)

Alamino VA, Mascanfroni ID, Montesinos MM, Gigena N, Donadio AC, Blidner AG, Milotich SI, Cheng S-Y, Masini-Repiso AM, Rabinovich GA, et al. 2015 Antitumor responses stimulated by dendritic cells are improved by triiodothyronine binding to the thyroid hormone receptor $\beta$. Cancer Research 75 1265-1274. (doi:10.1158/0008-5472.CAN-14-1875)

Ali Gulcelik M, Ersoz Gulcelik N, Dinc S, Kuru B, Camlibel M \& Alagol H 2006 The incidence of hyperthyroidism in patients with thyroid cancer in an area of iodine deficiency. Journal of Surgical Oncology 94 35-39. (doi:10.1002/jso.20508)

Ananth AA, Tai L-H, Lansdell C, Alkayyal AA, Baxter KE, Angka L, Zhang J, Tanese de Souza C, Stephenson KB, Parato K, et al. 2016 Surgical stress abrogates pre-existing protective $\mathrm{T}$ cell mediated antitumor immunity leading to postoperative cancer recurrence. PLoS ONE 11 e0155947. (doi:10.1371/journal.pone.0155947)

Andersen MH, Fensterle J, Ugurel S, Reker S, Houben R, Guldberg P, Berger TG, Schadendorf D, Trefzer U, Bröcker E-B, et al. 2004
๑ 2017 Society for Endocrinology Printed in Great Britain
Published by Bioscientifica Ltd 
Immunogenicity of constitutively active V599E BRaf. Cancer Research 64 5456-5460. (doi:10.1158/0008-5472.CAN-04-0937)

Andtbacka RHI, Kaufman HL, Collichio F, Amatruda T, Senzer N, Chesney J, Delman KA, Spitler LE, Puzanov I, Agarwala SS, et al. 2015 Talimogene laherparepvec improves durable response rate in patients with advanced melanoma. Journal of Clinical Oncology 33 2780-2788. (doi:10.1200/JCO.2014.58.3377)

Andtbacka RHI, Ross M, Puzanov I, Milhem M, Collichio F, Delman KA, Amatruda T, Zager JS, Cranmer L, Hsueh E, et al. 2016 Patterns of clinical response with Talimogene Laherparepvec (T-VEC) in patients with melanoma treated in the OPTiM phase III clinical trial. Annals of Surgical Oncology 23 4169-4177. (doi:10.1245/s10434-016-5286-0)

Angell TE, Lechner MG, Jang JK, Correa AJ, LoPresti JS \& Epstein AL $2014 a$ BRAF $\mathrm{V} 600 \mathrm{E}$ in papillary thyroid carcinoma is associated with increased programmed death ligand 1 expression and suppressive immune cell infiltration. Thyroid 24 1385-1393. (doi:10.1089/ thy.2014.0134)

Angell TE, Lechner MG, Jang JK, LoPresti JS \& Epstein AL 2014b MHC class I loss is a frequent mechanism of immune escape in papillary thyroid cancer that is reversed by interferon and selumetinib treatment in vitro. Clinical Cancer Research 20 6034-6044. (doi:10.1158/1078-0432.CCR-14-0879)

Angell TE, Lechner MG, Smith AM, Martin SE, Groshen SG, Maceri DR, Singer PA \& Epstein AL 2016 Circulating myeloid-derived suppressor cells predict differentiated thyroid cancer diagnosis and extent. Thyroid 26 381-389. (doi:10.1089/thy.2015.0289)

Apetoh L, Ghiringhelli F, Tesniere A, Obeid M, Ortiz C, Criollo A, Mignot G, Maiuri MC, Ullrich E, Saulnier P, et al. 2007 Toll-like receptor 4-dependent contribution of the immune system to anticancer chemotherapy and radiotherapy. Nature Medicine $\mathbf{1 3}$ 1050-1059. (doi:10.1038/nm1622)

Audenaerde JRM Van, De Waele J, Marcq E, Loenhout J Van, Lion E, Bergh JMJ Van Den, Jesenofsky R, Masamune A, Pauwels P, Lardon F et al. 2017 Interleukin-15 stimulates natural killer cell-mediated killing of both human pancreatic cancer and stellate cells. Oncotarget 8 56968-56979. (doi:10.18632/oncotarget.18185)

Bachleitner-Hofmann T, Friedl J, Hassler M, Hayden H, Dubsky P, Sachet M, Rieder E, Pfragner R, Brostjan C, Riss S, et al. 2009 Pilot trial of autologous dendritic cells loaded with tumor lysate(s) from allogeneic tumor cell lines in patients with metastatic medullary thyroid carcinoma. Oncology Reports 21 1585-1592. (doi:10.3892/ or_00000391)

Bailey P, Chang DK, Forget M-A, Lucas FAS, Alvarez HA, Haymaker C, Chattopadhyay C, Kim S-H, Ekmekcioglu S, Grimm EA, et al. 2016 Exploiting the neoantigen landscape for immunotherapy of pancreatic ductal adenocarcinoma. Scientific Reports 635848. (doi:10.1038/srep35848)

Balázs C, Leovey A, Szabo M \& Bako G 1980 Stimulating effect of triiodothyronine on cell-mediated immunity. European Journal of Clinical Pharmacology 17 19-23.

Baruch EN, Berg AL, Besser MJ, Schachter J \& Markel G 2017 Adoptive T cell therapy: an overview of obstacles and opportunities. Cancer 123 2154-2162. (doi:10.1002/cncr.30491)

Bastman JJ, Serracino HS, Zhu Y, Koenig MR, Mateescu V, Sams SB, Davies KD, Raeburn CD, McIntyre RC, Haugen BR, et al. 2016 Tumorinfiltrating $\mathrm{T}$ cells and the PD-1 checkpoint pathway in advanced differentiated and anaplastic thyroid cancer. Journal of Clinical Endocrinology and Metabolism 101 2863-2873. (doi:10.1210/jc.2015-4227)

Becker JC, Andersen MH, Hofmeister-Müller V, Wobser M, Frey L, Sandig C, Walter S, Singh-Jasuja H, Kämpgen E, Opitz A, et al. 2012 Survivin-specific T-cell reactivity correlates with tumor response and patient survival: a phase-II peptide vaccination trial in metastatic melanoma. Cancer Immunology, Immunotherapy: CII 61 2091-2103. (doi:10.1007/s00262-012-1266-9)

Bikas A, Kundra P, Desale S, Mete M, O'Keefe K, Clark BG, Wray L, Gandhi R, Barett C, Jelinek JS, et al. 2016 Phase 2 clinical trial of sunitinib as adjunctive treatment in patients with advanced differentiated thyroid cancer. European Journal of Endocrinology 174 373-380. (doi:10.1530/EJE-15-0930)

Binz E, Berchtold S, Beil J, Schell M, Geisler C, Smirnow I \& Lauer UM 2017 Chemovirotherapy of pancreatic adenocarcinoma by combining oncolytic vaccinia virus GLV-1h68 with nabpaclitaxel+gemcitabine. Molecular Therapy: Oncolytics 6 10-21. (doi:10.1016/j.omto.2017.04.001)

Biondi B \& Cooper DS 2010 Benefits of thyrotropin suppression versus the risks of adverse effects in differentiated thyroid cancer. Thyroid 20 135-146. (doi:10.1089/thy.2009.0311)

Bittencourt CS, Azzolini AE, Ferreira DA \& Assis-Pandochi AI 2007 Antibody responses in hyperthyroid rats. International Immunopharmacology 7 989-993.

Blalock JE, Johnson HM, Smith EM \& Tortes BA 1984 Enhancement of the in vitro antibody response by thyrotropin. Biochemical and Biophysical Research Communications 125 30-34.

Bongiovanni M, Rebecchini C, Saglietti C, Bulliard J-L, Marino L, de Leval L \& Sykiotis GP 2017 Very low expression of PD-L1 in medullary thyroid carcinoma. Endocrine-Related Cancer 24 L35-L38. (doi:10.1530/ERC-17-0104)

Brivio F, Fumagalli L, Lissoni P, Nardone A, Nespoli L, Fattori L, Denova M, Chiarelli M \& Nespoli A 2006 Pre-operative immunoprophylaxis with interleukin-2 may improve prognosis in radical surgery for colorectal cancer stage B-C. Anticancer Research 26 599-603.

Butterfield LH 2013 Dendritic cells in cancer immunotherapy clinical trials: are we making progress? Frontiers in Immunology $\mathbf{4} 454$. (doi:10.3389/fimmu.2013.00454)

Cabanillas ME, McFadden DG \& Durante C 2016 Thyroid cancer. Lancet 388 2783-2795. (doi:10.1016/S0140-6736(16)30172-6)

Capezzone M, Marchisotta S, Cantara S \& Pacini F 2009 Telomeres and thyroid cancer. Current Genomics 10 526-533. (doi:10.2174/13892020 9789503897)

Castellino SM, Geiger AM, Mertens AC, Leisenring WM, Tooze JA, Goodman P, Stovall M, Robison LL \& Hudson MM 2011 Morbidity and mortality in long-term survivors of Hodgkin lymphoma: a report from the Childhood Cancer Survivor Study. Blood 117 1806-1816. (doi:10.1182/blood-2010-04-278796)

Cheever MA, Allison JP, Ferris AS, Finn OJ, Hastings BM, Hecht TT, Mellman I, Prindiville SA, Viner JL, Weiner LM, et al. 2009 The prioritization of cancer antigens: a national cancer institute pilot project for the acceleration of translational research. Clinical Cancer Research 15 5323-5337. (doi:10.1158/1078-0432.CCR-09-0737)

Chen Z, Liu N, Zhu G, Dralle H \& Hoang-Vu C 2012 Targeting of the anti-apoptotic gene survivin in human thyroid carcinoma. International Journal of Molecular Medicine 30 465-472. (doi:10.3892/ ijmm.2012.1046

Chen L, Han X, Bedognetti D, Marincola F, Adema G \& Ljunggren H 2015 Anti-PD-1/PD-L1 therapy of human cancer: past, present, and future. Journal of Clinical Investigation 125 3384-3391. (doi:10.1172/ JCI80011)

Cheng S-P, Yang P-S, Chien M-N, Chen M-J, Lee J-J \& Liu C-L 2016 Aberrant expression of tumor-associated carbohydrate antigen Globo $\mathrm{H}$ in thyroid carcinoma. Journal of Surgical Oncology 114 853-858. (doi:10.1002/jso.24479)

Chiocca EA \& Rabkin SD 2014 Oncolytic viruses and their application to cancer immunotherapy. Cancer Immunology Research 2 295-300. (doi:10.1158/2326-6066.CIR-14-0015)

Cho J-S, Park M-H, Ryu Y-J \& Yoon J-H 2015 The neutrophil to lymphocyte ratio can discriminate anaplastic thyroid cancer against poorly or well differentiated cancer. Annals of Surgical Treatment and Research 88 187. (doi:10.4174/astr.2015.88.4.187)

Clemente CG, Mihm MC, Bufalino R, Zurrida S, Collini P \& Cascinelli N 1996 Prognostic value of tumor infiltrating lymphocytes in the vertical growth phase of primary cutaneous melanoma. Cancer $\mathbf{7 7}$ 
1303-1310. (doi:10.1002/(SICI)1097-0142(19960401)77:7<1303::AIDCNCR12>3.0.CO;2-5)

Coburn M, Teates D \& Wanebo HJ 1994 Recurrent thyroid cancer. Role of surgery versus radioactive iodine (I131). Annals of Surgery 219 587-595.

Cooper MA, Bush JE, Fehniger TA, Vandeusen JB, Waite RE, Aguila HL \& Caligiuri MA 2013 In vivo evidence for a dependence on interleukin 15 for survival of natural killer cells In vivo evidence for a dependence on interleukin 15 for survival of natural killer cells. Blood 100 3633-3638. (doi:10.1182/blood-2001-12-0293)

Couzin-Frankel J 2013 Cancer immunotherapy. Science 342 1432-1433. (doi:10.1126/science.342.6165.1432)

Cunha LL, Morari EC, Guihen ACT, Razolli D, Gerhard R, Nonogaki S, Soares FA, Vassallo J \& Ward LS 2012 Infiltration of a mixture of immune cells may be related to good prognosis in patients with differentiated thyroid carcinoma. Clinical Endocrinology 77 918-925. (doi:10.1111/j.1365-2265.2012.04482.x)

Cunha LL, Marcello MA, Nonogaki S, Morari EC, Soares FA, Vassallo J \& Ward LS 2015 CD8+ tumour-infiltrating lymphocytes and COX2 expression may predict relapse in differentiated thyroid cancer. Clinical Endocrinology 83 246-253. (doi:10.1111/cen.12586)

Dasgupta S, Tripathi PK, Bhattacharya-Chatterjee M, O'Malley B \& Chatterjee SK 2003 Recombinant vaccinia virus expressing IL-2 generates effective anti-tumor responses in an orthotopic murine model of head and neck carcinoma. Molecular Therapy 8 238-248.

Dhupkar P \& Gordon N 2017 Interleukin-2: old and new approaches to enhance immune-therapeutic efficacy. Advances in Experimental Medicine and Biology 995 33-51. (doi:10.1007/978-3-319-53156-4_2)

Donnelly OG, Errington-Mais F, Steele L, Hadac E, Jennings V, Scott K, Peach H, Phillips RM, Bond J, Pandha H, et al. 2013 Measles virus causes immunogenic cell death in human melanoma. Gene Therapy 20 7-15. (doi:10.1038/gt.2011.205)

Drake CG, Jaffee E \& Pardoll DM 2006 Mechanisms of immune evasion by tumors. Advances in Immunology 90 51-81. (doi:10.1016/S00652776(06)90002-9)

Dunn GP, Bruce AT, Ikeda H, Old LJ \& Schreiber RD 2002 Cancer immunoediting: from immunosurveillance to tumor escape. Nature Immunology 3 991-998. (doi:10.1038/ni1102-991)

Dunn GP, Old LJ \& Schreiber RD 2004 The immunobiology of cancer immunosurveillance and immunoediting. Immunity 21 137-148. (doi:10.1016/j.immuni.2004.07.017)

Duraiswamy J, Kaluza KM, Freeman GJ \& Coukos G 2013 Dual blockade of PD-1 and CTLA-4 combined with tumor vaccine effectively restores T-cell rejection function in tumors. Cancer Research $\mathbf{7 3}$ 3591-3603. (doi:10.1158/0008-5472.CAN-12-4100)

Engeland CE, Grossardt C, Veinalde R, Bossow S, Lutz D, Kaufmann JK, Shevchenko I, Umansky V, Nettelbeck DM, Weichert W, et al. 2014 CTLA-4 and PD-L1 checkpoint blockade enhances oncolytic measles virus therapy. Molecular Therapy 22 1949-1959. (doi:10.1038/ mt.2014.160)

Fang W, Ye L, Shen L, Cai J, Huang F, Wei Q, Fei X, Chen X, Guan H, Wang W, et al. 2014 Tumor-associated macrophages promote the metastatic potential of thyroid papillary cancer by releasing CXCL8. Carcinogenesis 35 1780-1787. (doi:10.1093/carcin/bgu060)

Farkona S, Diamandis EP \& Blasutig IM 2016 Cancer immunotherapy: the beginning of the end of cancer? BMC Medicine $\mathbf{1 4} 73$

Foster MP, Montecino-Rodriguez E \& Dorshkind K 1999 Proliferation of bone marrow pro-B cells is dependent on stimulation by the pituitary/thyroid axis. Journal of Immunology 163 5883-5890.

French JD, Weber ZJ, Fretwell DL, Said S, Klopper JP \& Haugen BR 2010 Tumor-associated lymphocytes and increased FoxP3+ regulatory $\mathrm{T}$ cell frequency correlate with more aggressive papillary thyroid cancer. Journal of Clinical Endocrinology and Metabolism 95 2325-2333. (doi:10.1210/jc.2009-2564)

Gabriele R, Letizia C, Borghese M, De Toma G, Celi M, Izzo L \& Cavallaro A 2003 Thyroid cancer in patients with hyperthyroidism. Hormone Research 60 79-83. (doi:10.1159/000071875)
Gabrilovich DI \& Nagaraj S 2009 Myeloid-derived-supressor cells as regulators of th eimmune system. Nature Reviews Immunology 9 162-174. (doi:10.1038/nri2506.Myeloid-derived-suppressor)

Galanis E, Atherton PJ, Maurer MJ, Knutson KL, Dowdy SC, Cliby WA, Haluska P, Long HJ, Oberg A, Aderca I, et al. 2015 Oncolytic measles virus expressing the sodium iodide symporter to treat drug-resistant ovarian cancer. Cancer Research 75 22-30. (doi:10.1158/0008-5472. CAN-14-2533)

Galluzzi L, Kepp O \& Kroemer G 2013 Immunogenic cell death in radiation therapy. Oncoimmunology 2 e26536. (doi:10.4161/ onci.26536)

Galluzzi L, Buqué A, Kepp O, Zitvogel L \& Kroemer G 2016 Immunogenic cell death in cancer and infectious disease. Nature Reviews Immunology 17 97-111. (doi:10.1038/nri.2016.107)

Galon J, Costes A, Sanchez-Cabo F, Kirilovsky A, Mlecnik B, LagorcePages C, Tosolini M, Camus M, Berger A, Wind P, et al. 2006 Type, density, and location of immune cells within human colorectal tumours predict clinical outcome. Science 318 1960-1964. (doi:10.1126/science.1229223)

Gardai SJ, McPhillips KA, Frasch SC, Janssen WJ, Starefeldt A, MurphyUllrich JE, Bratton DL, Oldenborg P-A, Michalak M \& Henson PM 2005 Cell-surface calreticulin initiates clearance of viable or apoptotic cells through trans-activation of LRP on the phagocyte. Cell 123 321-334. (doi:10.1016/j.cell.2005.08.032)

Garg AD \& Agostinis P 2016 Editorial: immunogenic cell death in cancer: from benchside research to bedside reality. Frontiers in Immunology 7 110. (doi:10.3389/fimmu.2016.00110)

Garrido F, Aptsiauri N, Doorduijn EM, Garcia Lora AM \& van Hall T 2016 The urgent need to recover MHC class I in cancers for effective immunotherapy. Current Opinion in Immunology 39 44-51. (doi:10.1016/j.coi.2015.12.007)

Gentles AJ, Newman AM, Liu CL, Bratman SV, Feng W, Kim D, Nair VS, $\mathrm{Xu}$ Y, Khuong A, Hoang CD, et al. 2015 The prognostic landscape of genes and infiltrating immune cells across human cancers. Nature Medicine 21 938-945. (doi:10.1038/nm.3909)

Ghiringhelli F, Apetoh L, Tesniere A, Aymeric L, Ma Y, Ortiz C, Vermaelen K, Panaretakis T, Mignot G, Ullrich E, et al. 2009 Activation of the NLRP3 inflammasome in dendritic cells induces IL-1 $\beta-$ dependent adaptive immunity against tumors. Nature Medicine 15 1170-1178. (doi:10.1038/nm.2028)

Gholami S, Haddad D, Chen C-H, Chen NG, Zhang Q, Zanzonico PB, Szalay AA \& Fong Y 2011 Novel therapy for anaplastic thyroid carcinoma cells using an oncolytic vaccinia virus carrying the human sodium iodide symporter. Surgery 150 1040-1047. (doi:10.1016/j.surg.2011.09.010)

Gooden MJM, de Bock GH, Leffers N, Daemen T \& Nijman HW 2011 The prognostic influence of tumour-infiltrating lymphocytes in cancer: a systematic review with meta-analysis. British Journal of Cancer 105 93-103. (doi:10.1038/bjc.2011.189)

Guan M, Romano G, Coroniti R \& Henderson EE 2014 Progress in oncolytic virotherapy for the treatment of thyroid malignant neoplasm. Journal of Experimental and Clinical Cancer Research 3391. (doi:10.1186/s13046-014-0091-8)

Guan X, Wang P, Chi J, Zhao S \& Wang F 2017 Relationships of BRAF mutation and HMGB1 to papillary thyroid carcinoma. Biochemical and Biophysical Research Communications 486 898-903. (doi:10.1016/j.bbrc.2017.03.117)

Guillerey C, Huntington ND \& Smyth MJ 2016 Targeting natural killer cells in cancer immunotherapy. Nature Immunology 17 1025-1036. (doi:10.1038/ni.3518)

Gunda V, Cogdill AP, Bernasconi MJ, Wargo JA \& Parangi S 2013 Potential role of 5-aza-2'-deoxycytidine induced MAGE-A4 expression in immunotherapy for anaplastic thyroid cancer. Surgery 154 1456-1462. (doi:10.1016/j.surg.2013.07.009)

Gunda V, Frederick DT, Bernasconi MJ, Wargo JA \& Parangi S 2014 A potential role for immunotherapy in thyroid cancer by enhancing

Published by Bioscientifica Ltd. 
NY-ESO-1 cancer antigen expression. Thyroid 24 1241-1250. (doi:10.1089/thy.2013.0680)

Guo C, Manjili MH, Subjeck JR, Sarkar D, Fisher PB \& Wang X-Y 2013 Therapeutic cancer vaccines: past, present, and future. Advances in Cancer Research 119 421-475. (doi:10.1016/B978-0-12-4071902.00007-1)

Gupta S, Patel A, Folstad A, Fenton C, Dinauer CA, Tuttle RM, Conran R \& Francis GL 2001 Infiltration of differentiated thyroid carcinoma by proliferating lymphocytes is associated with improved disease-free survival for children and young adults. Journal of Clinical Endocrinology and Metabolism 86 1346-1354. (doi:10.1210/jcem.86.3.7310)

Halvorsen EC, Mahmoud SM \& Bennewith KL 2014 Emerging roles of regulatory T cells in tumour progression and metastasis. Cancer and Metastasis Reviews 33 1025-1041. (doi:10.1007/s10555-014-9529-x)

Han JM, Kim TY, Jeon MJ, Yim JH, Kim WG, Song DE, Hong SJ, Bae SJ, Kim H-K, Shin M-H, et al. 2013 Obesity is a risk factor for thyroid cancer in a large, ultrasonographically screened population. European Journal of Endocrinology 168 879-886. (doi:10.1530/EJE-13-0065)

Harimoto H, Shimizu M, Nakagawa Y, Nakatsuka K, Wakabayashi A, Sakamoto C \& Takahashi H 2013 Inactivation of tumor-specific CD8+ CTLs by tumor-infiltrating tolerogenic dendritic cells. Immunology and Cell Biology 91 545-555. (doi:10.1038/icb.2013.38)

Harrington KJ, Hingorani M, Tanay MA, Hickey J, Bhide SA, Clarke PM, Renouf LC, Thway K, Sibtain A, McNeish IA, et al. 2010 Phase I/II study of oncolytic HSVGM-CSF in combination with radiotherapy and cisplatin in untreated stage III/IV squamous cell cancer of the head and neck. Clinical Cancer Research 16 4005-4015. (doi:10.1158/1078-0432.CCR-10-0196)

Hilly O, Koren R, Raz R, Rath-Wolfson L, Mizrachi A, Hamzany Y, Bachar G \& Shpitzer T 2013 The role of S100-positive dendritic cells in the prognosis of papillary thyroid carcinoma. American Journal of Clinical Pathology 139 87-92. (doi:10.1309/AJCPAKYDO56NKMYZ)

Hodkinson CF, Simpson EE, Beattie JH, O'Connor JM, Campbell DJ, Strain JJ \& Wallace JMW 2009 Preliminary evidence of immune function modulation by thyroid hormones in healthy men and women aged 55-70 years. Journal of Endocrinology 202 55-63. (doi:10.1677/JOE-08-0488)

Hogan BV, Peter MB, Shenoy HG, Horgan K \& Hughes TA 2011 Surgery induced immunosuppression. Surgeon 9 38-43. (doi:10.1016/j. surge.2010.07.011)

Howlader N, Noone AM, Krapcho M, Miller D, Bishop K, Altekruse SF, Kosary CL, Yu M, Ruhl J, Tatalovich Z, et al. 2016 SEER cancer statistics review, 1975-2013. Bethesda, MD, USA: National Cancer Institute. (available at: https://seer.cancer.gov/archive/ csr/1975_2013/)

Imam S, Paparodis R, Sharma D \& Jaume JC 2014 Lymphocytic profiling in thyroid cancer provides clues for failure of tumour immunity. Endocrine-Related Cancer 21 505-516. (doi:10.1038/jid.2014.371)

Jafarzadeh A, Poorgholami M, Izadi N, Nemati M \& Rezayati M 2010 Immunological and hematological changes in patients with hyperthyroidism or hypothyroidism. Clinical \& Investigative Medicine 33 E271-E279.

Jaime-Ramirez AC, Mundy-Bosse BL, Kondadasula S, Jones NB, Roda JM, Mani A, Parihar R, Karpa V, Papenfuss TL, LaPerle KM, et al. 2011IL12 enhances the antitumor actions of trastuzumab via NK cell IFN- $\gamma$ production. Journal of Immunology 186 3401-3409. (doi:10.4049/ jimmunol.1000328)

Janas ML, Groves P, Kienzle N \& Kelso A 2005 IL-2 regulates perforin and granzyme gene expression in CD8+ T cells independently of its effects on survival and proliferation. Journal of Immunology $\mathbf{1 7 5}$ 8003-8010.

Jang J-E, Hajdu CH, Liot C, Miller G, Dustin ML, Bar-Sagi D, Nomura T, Sakaguchi S, Frey AB, Ruocco MG, et al. 2017 Crosstalk between regulatory $\mathrm{T}$ cells and tumor-associated dendritic cells negates antitumor immunity in pancreatic cancer. Cell Reports 20 558-571. (doi:10.1016/j.celrep.2017.06.062)
Jiang Y, Li Y \& Zhu B 2015 T-cell exhaustion in the tumor microenvironment. Cell Death and Disease 6 e1792. (doi:10.1038/ cddis.2015.162)

Jung KY, Cho SW, Kim YA, Kim D, Oh B-C, Park DJ \& Park YJ 2015 Cancers with higher density of tumor-associated macrophages were associated with poor survival rates. Journal of Pathology and Translational Medicine 49 318-324. (doi:10.4132/jptm.2015.06.01)

Junger WG 2011 Immune cell regulation by autocrine purinergic signalling. Nature Reviews Immunology 11 201-212. (doi:10.1038/ nri2938)

Kang TH, Mao C-P, He L, Tsai Y-C, Liu K, La V, Wu T-C \& Hung C-F 2012 Tumor-targeted delivery of IL-2 by NKG2D leads to accumulation of antigen-specific CD8+ T cells in the tumor loci and enhanced antitumor effects. PLoS ONE 7 e35141. (doi:10.1371/journal.pone.0035141)

Kang R, Zhang Q, Zeh HJ, Lotze MT \& Tang D 2013 HMGB1 in cancer: good, bad, or both? Clinical Cancer Research 19 4046-4057. (doi:10.1158/1078-0432.CCR-13-0495)

Kantoff PW, Higano CS, Shore ND, Berger ER, Small EJ, Penson DF, Redfern CH, Ferrari AC, Dreicer R, Sims RB, et al. 2010 Sipuleucel-T immunotherapy for castration-resistant prostate cancer. New England Journal of Medicine 363 411-422. (doi:10.1056/NEJMoa1001294)

Kaufman HL, Kohlhapp FJ \& Zloza A 2015 Oncolytic viruses: a new class of immunotherapy drugs. Nature Reviews Drug Discovery 14 642-662. (doi:10.1038/nrd4663)

Kent WDT, Hall SF, Isotalo PA, Houlden RL, George RL \& Groome PA 2007 Increased incidence of differentiated thyroid carcinoma and detection of subclinical disease. Canadian Medical Association Journal 177 1357-1361. (doi:10.1503/cmaj.061730)

Kilfoy BA, Zheng T, Holford TR, Han X, Ward MH, Sjodin A, Zhang Y, Bai Y, Zhu C, Guo GL, et al. 2009 International patterns and trends in thyroid cancer incidence, 1973-2002. Cancer Causes and Control: CCC 20 525-531. (doi:10.1007/s10552-008-9260-4)

Kim S, Cho SW, Min HS, Kim KM, Yeom GJ, Kim EY, Lee KE, Yun YG, Park DJ \& Park YJ 2013 The expression of tumor-associated macrophages in papillary thyroid carcinoma. Endocrinology and Metabolism 28 192-198. (doi:10.3803/EnM.2013.28.3.192)

Kim H, Kim TH, Choe J-H, Kim J-H, Kim JS, Oh YL, Hahn SY, Shin JH, Chi SAh, Jung S-H, et al. 2017 Patterns of initial recurrence in completely resected papillary thyroid carcinoma. Thyroid $\mathbf{2 7}$ 908-914. (doi:10.1089/thy.2016.0648)

Kirschner LS, Qamri Z, Kari S \& Ashtekar A 2016 Mouse models of thyroid cancer: A 2015 update. Molecular and Cellular Endocrinology 421 18-27. (doi:10.1016/j.mce.2015.06.029)

Klein JR 2006 The immune system as a regulator of thyroid hormone activity. Experimental Biology and Medicine 231 229-236. (doi:10.1177 /153537020623100301)

Koks CA, Garg AD, Ehrhardt M, Riva M, Vandenberk L, Boon L, De Vleeschouwer S, Agostinis P, Graf N \& Van Gool SW 2015 Newcastle disease virotherapy induces long-term survival and tumorspecific immune memory in orthotopic glioma through the induction of immunogenic cell death. International Journal of Cancer 136 E313-E325. (doi:10.1002/ijc.29202)

Kuo C-Y, Liu T-P, Yang P-S \& Cheng S-P 2017 Characteristics of lymphocyte-infiltrating papillary thyroid cancer. Journal of Cancer Research and Practice 4 95-99. (doi:10.1016/j.jcrpr.2017.03.003)

Kuroda S, Fujiwara T, Shirakawa Y, Yamasaki Y, Yano S, Uno F, Tazawa H, Hashimoto Y, Watanabe Y, Noma K, et al. 2010 Telomerasedependent oncolytic adenovirus sensitizes human cancer cells to ionizing radiation via inhibition of DNA repair machinery. Cancer Research 70 9339-9348. (doi:10.1158/0008-5472.CAN-10-2333)

Kuryk L, Haavisto E, Garofalo M, Capasso C, Hirvinen M, Pesonen S, Ranki T, Vassilev L \& Cerullo V 2016 Synergistic anti-tumor efficacy of immunogenic adenovirus ONCOS-102 (Ad5/3-D24-GM-CSF) and standard of care chemotherapy in preclinical mesothelioma model. International Journal of Cancer 139 1883-1893. (doi:10.1002/ ijc.30228) 
Kuwabara K, Nishishita T, Morishita M, Oyaizu N, Yamashita S, Kanematsu T, Obara T, Mimura Y, Inoue Y, Kaminishi M, et al. 2007 Results of a phase I clinical study using dendritic cell vaccinations for thyroid cancer. Thyroid 17 53-58. (doi:10.1089/thy.2006.0178)

Ladoire S, Penault-Llorca F, Senovilla L, Dalban C, Enot D, Locher C, Prada N, Poirier-Colame V, Chaba K, Arnould L, et al. 2015 Combined evaluation of LC3B puncta and HMGB1 expression predicts residual risk of relapse after adjuvant chemotherapy in breast cancer. Autophagy 11 1878-1890. (doi:10.1080/15548627. 2015.1082022)

Larkin J, Chiarion-Sileni V, Gonzalez R, Grob JJ, Cowey CL, Lao CD, Schadendorf D, Dummer R, Smylie M, Rutkowski P, et al. 2015 Combined nivolumab and ipilimumab or monotherapy in untreated melanoma. New England Journal of Medicine 373 23-34. (doi:10.1056/ NEJMoa1504030)

Lee J-H, Kim Y, Choi J-W \& Kim Y-S 2013a The association between papillary thyroid carcinoma and histologically proven Hashimoto's thyroiditis: a meta-analysis. European Journal of Endocrinology 168 343-349. (doi:10.1530/EJE-12-0903)

Lee HS, Kim SW, Hong JC, Jung SB, Jeon C-H, Park JW, Park SY \& Lee KD $2013 b$ Expression of MAGE A1-6 and the clinical characteristics of papillary thyroid carcinoma. Anticancer Research $\mathbf{3 3}$ 1731-1735.

Lennerz V, Gross S, Gallerani E, Sessa C, Mach N, Boehm S, Hess D, von Boehmer L, Knuth A, Ochsenbein AF, et al. 2014 Immunologic response to the survivin-derived multi-epitope vaccine EMD640744 in patients with advanced solid tumors. Cancer Immunology, Immunotherapy 63 381-394. (doi:10.1007/s00262-013-1516-5)

Liu C-L, Lee J-J, Liu T-P, Chang Y-C, Hsu Y-C \& Cheng S-P 2013 Blood neutrophil-to-lymphocyte ratio correlates with tumor size in patients with differentiated thyroid cancer. Journal of Surgical Oncology 107 493-497. (doi:10.1002/jso.23270)

Liu C, Liu Z, Chen T, Zeng W, Guo Y \& Huang T 2016 TERT promoter mutation and its association with clinicopathological features and prognosis of papillary thyroid cancer: a meta-analysis. Scientific Reports 6 36990. (doi:10.1038/srep36990)

Liu E, Tong Y, Dotti G, Shaim H, Savoldo B, Mukherjee M, Orange J, Wan X, Lu X, Reynolds A, et al. 2017 Cord blood NK cells engineered to express IL-15 and CD19-targeted CAR show long-term persistence and potent anti-tumour activity. Leukemia [in press]. (doi:10.1038/ leu.2012.118)

Lönnroth C, Andersson M, Arvidsson A, Nordgren S, Brevinge H, Lagerstedt K \& Lundholm K 2008 Preoperative treatment with a non-steroidal anti-inflammatory drug (NSAID) increases tumor tissue infiltration of seemingly activated immune cells in colorectal cancer. Cancer Immunity 85.

Maio M, Coral S, Sigalotti L, Elisei R, Romei C, Rossi G, Cortini E, Colizzi F, Fenzi G, Altomonte M, et al. 2003 Analysis of cancer/testis antigens in sporadic medullary thyroid carcinoma: expression and humoral response to NY-ESO-1. Journal of Clinical Endocrinology and Metabolism 88 748-754. (doi:10.1210/jc.2002-020830)

Mardente S, Mari E, Massimi I, Fico F, Faggioni A, Pulcinelli F, Antonaci A \& Zicari A 2015 HMGB1-induced cross talk between PTEN and miRs 221/222 in thyroid cancer. BioMed Research International 2015 1-7. (doi:10.1155/2015/512027)

Markert JM, Razdan SN, Kuo H-C, Cantor A, Knoll A, Karrasch M, Nabors LB, Markiewicz M, Agee BS, Coleman JM, et al. 2014 A phase 1 trial of oncolytic HSV-1, G207, given in combination with radiation for recurrent GBM demonstrates safety and radiographic responses. Molecular Therapy 22 1048-1055. (doi:10.1038/ mt.2014.22)

Marvel D \& Gabrilovich DI 2015 Myeloid-derived suppressor cells in the tumor microenvironment: expect the unexpected. Journal Clinical Investigation 125 3356-3364. (doi:10.1172/JCI80005.Definition)

Mascanfroni I, Montesinos Mdel M, Susperreguy S, Cervi L, Ilarregui JM, Ramseyer VD, Masini-Repiso AM, Targovnik HM, Rabinovich GA \&
Pellizas CG 2008 Control of dendritic cell maturation and function by triiodothyronine. FASEB Journal 22 1032-1042. (doi:10.1096/fj.078652com)

Matsubayashi S, Kawai K, Matsumoto Y, Makuta T, Morita T, Hirai K, Matuzuka F, Kakudoh K, Kuma K \& Tamai H 1995 The correlation between papillary thyroid carcinoma and lymphocytic infiltration in the thyroid gland. Journal of Clinical Endocrinology and Metabolism $\mathbf{8 0}$ 3421-3424

Mazeh H \& Chen H 2011 Advances in surgical therapy for thyroid cancer. Nature Reviews Endocrinology 7 581-588. (doi:10.1038/ nrendo.2011.140)

Mazzaferri EL \& Jhiang SM 1994 Long-term impact of initial surgical and medical therapy on papillary and follicular thyroid cancer. American Journal of Medicine 97 418-428. (doi:10.1016/00029343(94)90321-2)

Melo DH, Mamede RCM, Neder L, Saggioro FP, Figueiredo DLA, Araújo da Silva W, Jungbluth AA \& Zago MA 2011 Expression of mage-A4 and mage-C1 tumor-associated antigen in benign and malignant thyroid diseases. Head and Neck 33 1426-1432. (doi:10.1002/ hed.21616)

Melo M, Gaspar da Rocha A, Batista R, Vinagre J, Martins MJ, Costa G, Ribeiro C, Carrilho F, Leite V, Lobo C, et al. 2017 TERT, BRAF, and NRAS in primary thyroid cancer and metastatic disease. Journal of Clinical Endocrinology and Metabolism 102 1898-1907. (doi:10.1210/ jc.2016-2785)

Michaud M, Martins I, Sukkurwala AQ, Adjemian S, Ma Y, Pellegatti P, Shen S, Kepp O, Scoazec M, Mignot G, et al. 2011 Autophagydependent anticancer immune responses induced by chemotherapeutic agents in mice. Science 334 1573-1577. (doi:10.1126/science.1208347)

Miyazaki A, Kobayashi J, Torigoe T, Hirohashi Y, Yamamoto T, Yamaguchi A, Asanuma H, Takahashi A, Michifuri Y, Nakamori K, et al. 2011 Phase I clinical trial of survivin-derived peptide vaccine therapy for patients with advanced or recurrent oral cancer. Cancer Science 102 324-329. (doi:10.1111/j.1349-7006.2010.01789.x)

Morgan RA, Chinnasamy N, Abate-Daga DD, Gros A, Robbins P Zheng Z, Feldman S, Yang J, Sherry R, Phan GQ, et al. 2013 Cancer regression and neurologic toxicity following anti-MAGE- A3 TCR gene therapy. Journal of Immunotherapy 36 133-151. (doi:10.1097/ CJI.0b013e3182829903.Cancer)

Morris LGT, Sikora AG, Tosteson TD \& Davies L 2013 The increasing incidence of thyroid cancer: the influence of access to care. Thyroid 23 885-891. (doi:10.1089/thy.2013.0045)

Muzza M, Colombo C, Rossi S, Tosi D, Cirello V, Perrino M, De Leo S, Magnani E, Pignatti E, Vigo B, et al. 2015 Telomerase in differentiated thyroid cancer: promoter mutations, expression and localization. Molecular and Cellular Endocrinology 399 288-295. (doi:10.1016/j.mce.2014.10.019)

Nabhan F \& Ringel MD 2017 Thyroid nodules and cancer managemen guidelines: comparisons and controversies. Endocrine-Related Cancer 24 R13-R26. (doi:10.1530/ERC-16-0432)

Najjar YG \& Finke JH 2013 Clinical perspectives on targeting of myeloid derived suppressor cells in the treatment of cancer. Frontiers in Oncology 3 49. (doi:10.3389/fonc.2013.00049)

Netea-Maier RT, Hunsucker SW, Hoevenaars BM, Helmke SM, Slootweg PJ, Hermus AR, Haugen BR \& Duncan MW 2008 Discovery and validation of protein abundance differences between follicular thyroid neoplasms. Cancer Research 68 1572-1580. (doi:10.1158/0008-5472.CAN-07-5020)

Obeid M, Tesniere A, Ghiringhelli F, Fimia GM, Apetoh L, Perfettini J-L, Castedo M, Mignot G, Panaretakis T, Casares N, et al. 2007 Calreticulin exposure dictates the immunogenicity of cancer cell death. Nature Medicine 13 54-61. (doi:10.1038/nm1523)

Papewalis C, Wuttke M, Seissler J, Meyer Y, Kessler C, Jacobs B, Ullrich E, Willenberg HS, Schinner S, Baehring T, et al. 2008 Dendritic cell vaccination with xenogenic polypeptide hormone http://erc.endocrinology-journals.org

DOI: 10.1530/ERC-17-0316
(C) 2017 Society for Endocrinology Printed in Great Britain 
induces tumor rejection in neuroendocrine cancer. Clinical Cancer Research 14 4298-4305. (doi:10.1158/1078-0432.CCR-08-0587)

Pardoll DM 2012 The blockade of immune checkpoints in cancer immunotherapy. Nature Reviews Cancer 12 252-264. (doi:10.1038/ nrc3239)

Parhar RS, Zou M, Al-Mohanna FA, Baitei EY, Assiri AM, Meyer BF \& Shi Y 2016 IL-12 immunotherapy of BrafV600E-induced papillary thyroid cancer in a mouse model. Laboratory Investigation 96 89-97. (doi:10.1038/labinvest.2015.126)

Passaro C, Abagnale A, Libertini S, Volpe M, Botta G, Cella L, Pacelli R, Hallden G, Gillespie D \& Portella G 2013 Ionizing radiation enhances d1922-947-mediated cell death of anaplastic thyroid carcinoma cells. Endocrine-Related Cancer 20 633-647. (doi:10.1530/ ERC-13-0001)

Passaro C, Borriello F, Vastolo V, Di Somma S, Scamardella E, Gigantino V Franco R, Marone G \& Portella G 2016 The oncolytic virus dl922-947 reduces IL-8/CXCL8 and MCP-1/CCL2 expression and impairs angiogenesis and macrophage infiltration in anaplastic thyroid carcinoma. Oncotarget 7 1500-1515. (doi:10.18632/oncotarget.6430)

Provinciali M, Di Stephano G \& Fabris N 1992 Improvement in the proliferative capacity and natural killer cell activity of murine spleen lymphocytes by thyrotropin. International Journal of Immunopharmacology 14 865-870. (doi:10.1016/01920561(92)90085-Y)

Reits EA, Hodge JW, Herberts CA, Groothuis TA, Chakraborty M, Wansley EK, Camphausen K, Luiten RM, de Ru AH, Neijssen J, et al. 2006 Radiation modulates the peptide repertoire, enhances MHC class I expression, and induces successful antitumor immunotherapy. Journal of Experimental Medicine 203 1259-1271. (doi:10.1084/ jem.20052494)

Rizvi NA, Hellmann MD, Snyder A, Kvistborg P, Makarov V, Havel JJ, Lee W, Yuan J, Wong P, Ho TS, et al. 2015 Mutational landscape determines sensitivity to PD-1 blockade in non-small cell lung cancer. Science 348 124-128. (doi:10.1126/science.aaa1348)

Rosa LF, Safi DA \& Curi R 1995 Effect of hypo- and hyperthyroidism on the function and metabolism of macrophages in rats. Cell Biochemistry \& Function 13 141-147.

Rosenberg SA \& Restifo NP 2015 Adoptive cell transfer as personalized immunotherapy for human cancer. Science 348 62-68.

Ruggeri R, Campennì A, Giuffrè G, Giovanella L, Siracusa M, Simone A, Branca G, Scarfì R, Trimarchi F, Ieni A, et al. 2016 HER2 analysis in sporadic thyroid cancer of follicular cell origin. International Journal of Molecular Sciences 17 2040. (doi:10.3390/ijms17122040)

Ryder M, Ghossein RA, Ricarte-filho JCM, Knauf JA \& Fagin JA 2009 Associated With decreased survival in advanced thyroid cancer. Cancer 15 1069-1074. (doi:10.1677/ERC-08-0036.Increased)

Sandri S, De Sanctis F, Lamolinara A, Boschi F, Poffe O, Trovato R, Fiore A, Sartori S, Sbarbati A, Bondanza A, et al. 2017 Effective control of acute myeloid leukaemia and acute lymphoblastic leukaemia progression by telomerase specific adoptive T-cell therapy. Oncotarget [in press]. (doi:10.18632/oncotarget.18115)

Sato E, Olson SH, Ahn J, Bundy B, Nishikawa H, Qian F, Jungbluth AA, Frosina D, Gnjatic S, Ambrosone C, et al. 2005 Intraepithelial CD8+ tumor-infiltrating lymphocytes and a high $\mathrm{CD} 8+$ /regulatory $\mathrm{T}$ cell ratio are associated with favorable prognosis in ovarian cancer. PNAS 102 18538-18543. (doi:10.1073/pnas.0509182102)

Schreiber RD, Old LJ \& Smyth MJ 2011 Cancer immunoediting: integrating immunity's roles in cancer suppression and promotion. Science 331 1565-1570. (doi:10.1126/science.1203486)

Schwartz Y, Avraham R, Benish M, Rosenne E \& Ben-Eliyahu S 2008 Prophylactic IL-12 treatment reduces postoperative metastasis: mediation by increased numbers but not cytotoxicity of NK cells. Breast Cancer Research and Treatment 107 211-223. (doi:10.1007/ s10549-007-9540-9)

Scouten WT \& Francis GL 2014 Thyroid cancer and the immune system: a model for effective immune surveillance. Expert Review of
Endocrinology and Metabolism 1 353-366. (doi:10.1586/ 17446651.1.3.353)

Sharma SD, Tsai V \& Proffitt MR 1982 Enhancement of mouse natural killer cell activity by thyroxine. Cellular Immunology 73 83-97.

Somasundaram R, Swoboda R, Caputo L, Otvos L, Weber B, Volpe P, van Belle P, Hotz S, Elder DE, Marincola FM, et al. 2006 Human leukocyte antigen-A2-restricted CTL responses to mutated BRAF peptides in melanoma patients. Cancer Research 66 3287-3293. (doi:10.1158/0008-5472.CAN-05-1932)

Son C-H, Lee H-R, Koh E-K, Shin D-Y, Bae J-H, Yang K \& Park Y-S 2016 Combination treatment with decitabine and ionizing radiation enhances tumor cells susceptibility of T cells. Scientific Reports 6 32470. (doi:10.1038/srep32470)

Steinman RM 1991 The dendritic cell system and its role in immunogenicity. Annual Review of Immunology 9 271-296. (doi:10.1146/annurev.iy.09.040191.001415)

Straathof KC, Pulè MA, Yotnda P, Dotti G, Vanin EF, Brenner MK, Heslop HE, Spencer DM \& Rooney CM 2005 An inducible caspase 9 safety switch for T-cell therapy. Blood 105 4247-4254. (doi:10.1182/ blood-2004-11-4564)

Suzuki S, Shibata M, Gonda K, Kanke Y, Ashizawa M, Ujiie D, Suzushino S, Nakano K, Fukushima T, Sakurai K, et al. 2013 Immunosuppression involving increased myeloid-derived suppressor cell levels, systemic inflammation and hypoalbuminemia are present in patients with anaplastic thyroid cancer. Molecular and Clinical Oncology 1 959-964. (doi:10.3892/mco.2013.170)

Tai L-H \& Auer R 2014 Attacking postoperative metastases using perioperative oncolytic viruses and viral vaccines. Frontiers in Oncology 4 217. (doi:10.3389/fonc.2014.00217)

Tai L-H, de Souza CT, Belanger S, Ly L, Alkayyal AA, Zhang J, Rintoul JL, Ananth AA, Lam T, Breitbach CJ, et al. 2013 Preventing postoperative metastatic disease by inhibiting surgery-induced dysfunction in natural killer cells. Cancer Research 73 97-107. (doi:10.1158/0008-5472.CAN-12-1993)

Tai L-H, Tanese de Souza C, Sahi S, Zhang J, Alkayyal AA, Ananth AA \& Auer RAC 2014 A mouse tumor model of surgical stress to explore the mechanisms of postoperative immunosuppression and evaluate novel perioperative immunotherapies. Journal of Visualized Experiments 85 e51253. (doi:10.3791/51253)

Takeuchi Y \& Nishikawa H 2016 Roles of regulatory T cells in cancer immunity. International Immunology 28 401-409. (doi:10.1093/ intimm/dxw025)

Tamang DL, Redelman D, Alves BN, Vollger L, Bethley C \& Hudig D 2006 Induction of granzyme B and T cell cytotoxic capacity by IL-2 or IL-15 without antigens: multiclonal responses that are extremely lytic if triggered and short-lived after cytokine withdrawal. Cytokine 36 148-159. (doi:10.1016/j.cyto.2006.11.008)

Teng F, Meng X, Kong L, Mu D, Zhu H, Liu S, Zhang J \& Yu J 2015 Tumor-infiltrating lymphocytes, forkhead box P3, programmed death ligand-1, and cytotoxic T lymphocyte-associated antigen-4 expressions before and after neoadjuvant chemoradiation in rectal cancer. Translational Research 166 721.e1-732.e1. (doi:10.1016/j. trsl.2015.06.019)

Tey S-K 2014 Adoptive T-cell therapy: adverse events and safety switches. Clinical and Translational Immunology 3 e17. (doi:10.1038/ cti.2014.11)

Tran Janco JM, Lamichhane P, Karyampudi L \& Knutson KL 2015 Tumor-infiltrating dendritic cells in cancer pathogenesis. Journal of Immunology 194 2985-2991. (doi:10.4049/jimmunol.1403134)

Travis LB, Fossa SD, Schonfeld SJ, McMaster ML, Lynch CF, Storm H, Hall P, Holowaty E, Andersen A, Pukkala E, et al. 2005 Second cancers among 40576 testicular cancer patients: focus on long-term survivors. Journal of the National Cancer Institute 97 1354-1365. (doi:10.1093/jnci/dji278)

Trujillo MA, Oneal MJ, McDonough SJ \& Morris JC 2013 Viral dose, radioiodide uptake, and delayed efflux in adenovirus-mediated NIS

Published by Bioscientifica Ltc. 
radiovirotherapy correlates with treatment efficacy. Gene Therapy 20 567-574. (doi:10.1038/gt.2012.71)

Vanden Borre P, McFadden DG, Gunda V, Sadow PM, Varmeh S, Bernasconi M, Jacks T \& Parangi S 2014 The next generation of orthotopic thyroid cancer models: immunocompetent orthotopic mouse models of BRAF ${ }^{6000}$-positive papillary and anaplastic thyroid carcinoma. Thyroid 24 705-714. (doi:10.1089/thy.2013.0483)

Vedvyas Y, Shevlin E, Zaman M, Min IM, Amor-Coarasa A, Park S, Park S, Kwon K-W, Smith T, Luo Y, et al. 2016 Longitudinal PET imaging demonstrates biphasic CAR T cell responses in survivors. JCI Insight 1 e90064. (doi:10.1172/jci.insight.90064)

De Vito P, Incerpi S, Pedersen JZ, Luly P, Davis FD \& Davis PJ 2011 Thyroid hormones as modulators of immune activities at the cellular level. Thyroid 21 879-890. (doi:10.1089/thy.2010.0429)

Wagner J, Pfannenstiel V, Waldmann A, Bergs JWJ, Brill B, Huenecke S, Klingebiel T, Rödel F, Buchholz CJ, Wels WS, et al. 2017 A two-phase expansion protocol combining interleukin (IL)-15 and IL-21 improves natural killer cell proliferation and cytotoxicity against rhabdomyosarcoma. Frontiers in Immunology 8 676. (doi:10.3389/ fimmu.2017.00676

Waligórska-Stachura J, Andrusiewicz M, Sawicka-Gutaj N, Biczysko M, Jankowska A, Kubiczak M, Czarnywojtek A, Wrotkowska E \& Ruchała M 2014 Survivin delta Ex3 overexpression in thyroid malignancies. PLoS ONE 9 e100534. (doi:10.1371/journal. pone.0100534)

Wang LY, Smith AW, Palmer FL, Tuttle RM, Mahrous A, Nixon IJ, Patel SG, Ganly I, Fagin JA \& Boucai L 2015a Thyrotropin suppression increases the risk of osteoporosis without decreasing recurrence in ATA low- and intermediate-risk patients with differentiated thyroid carcinoma. Thyroid 25 300-307. (doi:10.1089/thy.2014.0287)

Wang Y, Zhang J, Wu Y, Ding Z-Y, Luo X-M, Liu J, Zhong W-N, Deng G-H, Xia X-Y, Deng Y-T, et al. 2015b Mannan-modified adenovirus targeting TERT and VEGFR-2: a universal tumour vaccine. Scientific Reports 5 11275. (doi:10.1038/srep11275)

Wang K, Xu J, Zhang T, Xue D, Wang K, Xu J, Zhang T \& Xue D 2016 Tumor-infiltrating lymphocytes in breast cancer predict the response to chemotherapy and survival outcome: a meta-analysis. Oncotarget 7 44288-44298. (doi:10.18632/oncotarget.9988)

Watanabe K, Iwatani Y, Hidaka Y, Watanabe M \& Amino N 1995 Longterm effects of thyroid hormone on lymphocyte subsets in spleens and thymuses of mice. Endocrine Journal 42 661-668.

Wennerberg E, Pfefferle A, Ekblad L, Yoshimoto Y, Kremer V, Kaminskyy VO, Juhlin CC, Höög A, Bodin I, Svjatoha V, et al. 2014 Human anaplastic thyroid carcinoma cells are sensitive to NK cellmediated lysis via ULBP2/5/6 and chemoattract NK cells. Clinical Cancer Research 20 5733-5744. (doi:10.1158/1078-0432. CCR-14-0291)
Wesolowski R, Markowitz J \& Carson WE III 2013 Myeloid derived suppressor cells - a new therapeutic target in the treatment of cancer. Journal for Immunotherapy of Cancer 1 10. (doi:10.1186/2051-1426-1-10)

Wilkinson MJ, Smith HG, McEntee G, Kyula-Currie J, Pencavel TD, Mansfield DC, Khan AA, Roulstone V, Hayes AJ \& Harrington KJ 2016 Oncolytic vaccinia virus combined with radiotherapy induces apoptotic cell death in sarcoma cells by down-regulating the inhibitors of apoptosis. Oncotarget 7 81208-81222. (doi:10.18632/ oncotarget.12820)

Xing M 2005 BRAF mutation in thyroid cancer. Endocrine-Related Cancer 12 245-262. (doi:10.1677/erc.1.0978)

Yan J, Pankhong P, Shin TH, Obeng-Adjei N, Morrow MP, Walters JN, Khan AS, Sardesai NY \& Weiner DB 2013 Highly optimized DNA vaccine targeting human telomerase reverse transcriptase stimulates potent antitumor immunity. Cancer Immunology Research 1 179-189.

Yeh N-C, Chou C-W, Weng S-F, Yang C-Y, Yen F-C, Lee S-Y, Wang J-J \& Tien K-J 2013 Hyperthyroidism and thyroid cancer risk: a population-based cohort study. Experimental and Clinical Endocrinology and Diabetes 121 402-406. (doi:10.1055/ s-0033-1341474)

Yu H, Huang X, Liu X, Jin H, Zhang G, Zhang Q \& Yu J 2013 Regulatory $\mathrm{T}$ cells and plasmacytoid dendritic cells contribute to the immune escape of papillary thyroid cancer coexisting with multinodular non-toxic goiter. Endocrine 44 172-181. (doi:10.1007/ s12020-012-9853-2)

Yuan A, Hsiao Y-J, Chen H-Y, Chen H-W, Ho C-C, Chen Y-Y, Liu Y-C, Hong T-H, Yu S-L, Chen JJW, et al. 2015 Opposite effects of M1 and M2 macrophage subtypes on lung cancer progression. Scientific Reports 5 14273. (doi:10.1038/srep14273)

Zhang L, Conejo-Garcia JR, Katsaros D, Gimotty PA, Massobrio M, Regnani G, Makrigiannakis A, Gray H, Schlienger K, Liebman MN, et al. 2003 Intratumoral T cells, recurrence, and survival in epithelial ovarian cancer. New England Journal of Medicine 348 203-213. (doi:10.1056/NEJMoa020177)

Zhang M, He Y, Sun X, Li Q, Wang W, Zhao A \& Di W 2014a A high M1/M2 ratio of tumor-associated macrophages is associated with extended survival in ovarian cancer patients. Journal of Ovarian Research 7 19. (doi:10.1186/1757-2215-7-19)

Zhang J, Tai L-H, Ilkow CS, Alkayyal AA, Ananth AA, de Souza CT, Wang J, Sahi S, Ly L, Lefebvre C, et al. 2014b Maraba MG1 virus enhances natural killer cell function via conventional dendritic cells to reduce postoperative metastatic disease. Molecular Therapy 22 1320-1332. (doi:10.1038/mt.2014.60)

Zwaenepoel K, Jacobs J, De Meulenaere A, Silence K, Smits E, Siozopoulou V, Hauben E, Rolfo C, Rottey S \& Pauwels P 2017 CD70 and PDL1 in anaplastic thyroid cancer - promising targets for immunotherapy. Histopathology 71 357-365. (doi:10.1111/his.13230)

Received in final form 29 July 2017

Accepted 13 September 2017

Accepted Preprint published online 14 September 2017
๑ 2017 Society for Endocrinology Printed in Great Britain
Published by Bioscientifica Ltd 